\title{
Application of Heterogeneous Catalysts for Biodiesel Production from Microalgal Oil-A Review
}

\author{
Mohammed O. Faruque ${ }^{1,2}$, Shaikh A. $\operatorname{Razzak}^{1}$ and Mohammad M. Hossain ${ }^{1, *(\mathbb{D}}$ \\ 1 Department of Chemical Engineering, King Fahd University of Petroleum \& Minerals, \\ Dhahran 31261, Saudi Arabia; g201706550@kfupm.edu.sa (M.O.F.); srazzak@kfupm.edu.sa (S.A.R.) \\ 2 Department of Petroleum \& Mining Engineering, Shahjalal University of Science and Technology, \\ Sylhet-3114, Bangladesh \\ * Correspondence: mhossain@kfupm.edu.sa; Tel.: +966-13-860-1478
}

Received: 18 July 2020; Accepted: 28 August 2020; Published: 7 September 2020

\begin{abstract}
The depletion of fossil fuel reserves and increased environmental concerns related to fossil fuel production and combustion has forced the global communities to search for renewable fuels. In this regard, microalgae-based biodiesel has been considered as one of the interesting alternatives. Biodiesel production from the cultivation of microalgae is eco-friendly and sustainable. Moreover, microalgae have several advantages over other bioenergy sources, including their good photosynthetic capacity and faster growth rates. The productivity of microalgae per unit land area is also significantly higher than that of terrestrial plants. The produced microalgae biomass is rich with high quality lipids, which can be converted into biodiesel by transesterification reactions. Generally, the transesterification reactions are carried out in the presence of a homogeneous or heterogeneous catalyst. The homogeneous catalysts have many disadvantages, including their single use, slow reaction rate and saponification issues due to the presence of fatty acids in the feedstock. The acidic nature of the homogeneous catalysts also causes equipment corrosion. On the other hand, the heterogeneous catalysts offer several advantages, including their reusability, higher reaction rate and selectivity, easy product/catalyst separation and low cost. Due to these facts, the development of solid phase transesterification catalysts have been receiving growing interest. The present review is focused on the use of heterogeneous catalysts for biodiesel production from microalgal oil as a reliable feedstock with a comparison to other available feedstocks. It also highlights optimal reaction conditions for maximum biodiesel yields, reusability of the solid catalysts, cost, and environmental impact. The superior lipid content of microalgae and the efficient concurrent esterification and transesterification of the solid acid-base catalysts can offer new advancements in biodiesel production.
\end{abstract}

Keywords: microalgal oil; transesterification; heterogeneous catalysts; acid-base catalysts; biodiesel

\section{Introduction}

Current worldwide energy resources are mostly based on non-renewable fossil fuels which are the major source of greenhouse gas $\mathrm{CO}_{2}$ emissions [1,2]. Statistics show that the combustion of fossil fuels contribute approximately $52 \%$ to total $\mathrm{CO}_{2}$ emissions by human activities [3,4]. Therefore, it is necessary to develop alternative energy sources/technologies in order to reduce the greenhouse gas effects drastically [5]. In this regard, renewable energy sources are the potential substitute and the only choice for the ever-increasing challenges [6]. In general, various renewable energy sources such as wind, solar, geothermal, wave, and biofuels are being considered as the alternatives to fossil fuel considering their cleanliness and potential for large scale production [7-10]. Despite having the numerous advantages of renewable energy sources, there are some drawbacks, including availability in specific regions, low efficiency, and high initial and maintenance costs $[11,12]$. Considering these 
different challenges related to renewable energy sources, biodiesel is a promising alternative for petroleum-based diesel fuel [13]. Biodiesel provides a significant return, it is nonhazardous, has an elevated flash point, has a soaring cetane number, high lubricity, little volatility or flammability, superior transport and storage properties, low carbon monoxide production and is eco-friendly [14,15].

Based on origin/feedstocks, biodiesel is categorized as first generation, second generation and third generation (Figure 1). Third generation biodiesels employ macro and micro algal oils as feedstock which are thought to be one of the very hopeful alternative resources for nonedible oils for biodiesel owing to their elevated oil content [16]. Biodiesel is described as methyl (or ethyl) esters of fatty acids produced during a reaction to split the triglyceride in fatty acids $[17,18]$. This reaction is known as the transesterification or esterification reaction according to the use of basic and acid catalysts $[19,20]$.

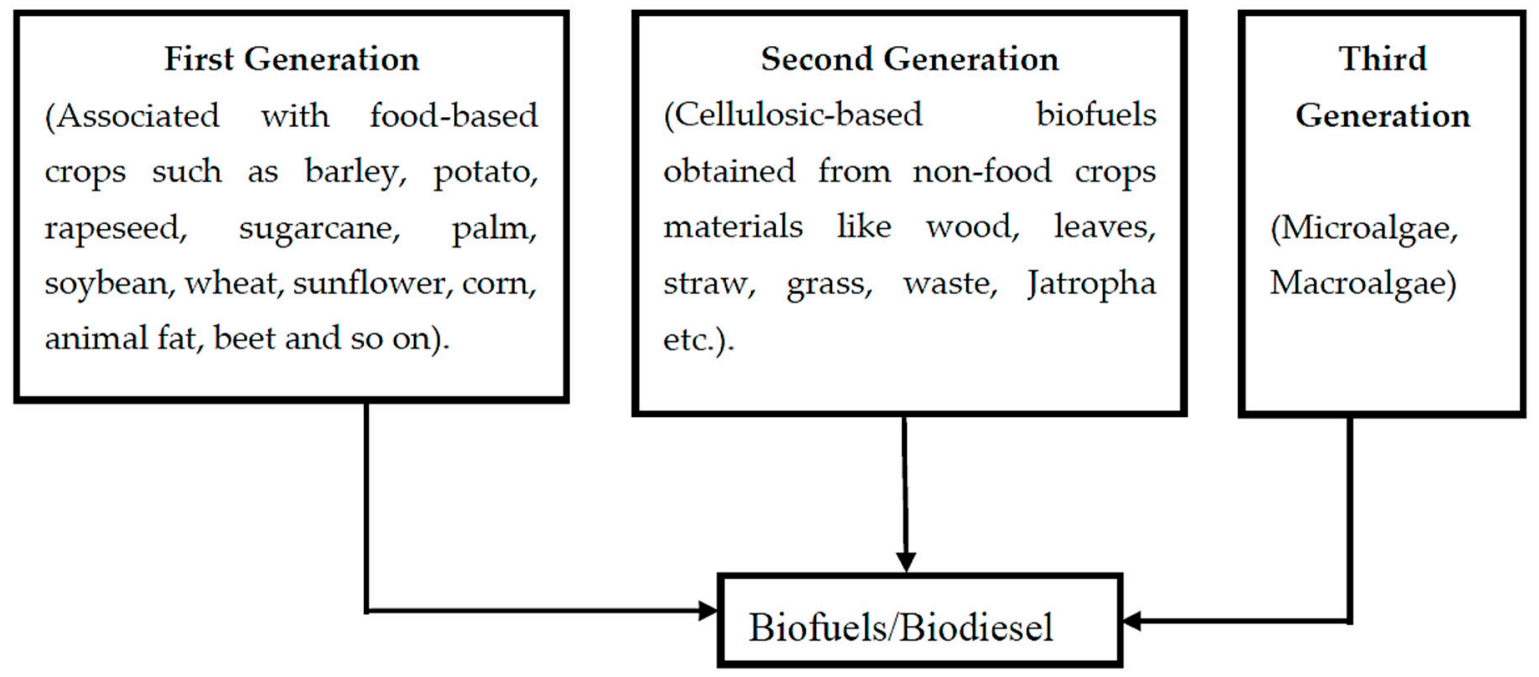

Figure 1. Generation of Biofuels/Biodiesel.

Conventionally, homogeneous alkaline catalysts, $\mathrm{CH}_{3} \mathrm{ONa}, \mathrm{NaOH}, \mathrm{KOH}$, and $\mathrm{CH}_{3} \mathrm{OK}$ are frequently applied for the production of biodiesel [21,22]. Abdullah et al. (2017) reported 93\% biodiesel yields from palm oil using $\mathrm{KOH}$ as a homogeneous catalyst [23]. Chamola et al. (2019) used $\mathrm{NaOH}$ in transesterification of dry algae and achieved maximum biodiesel yields of $87.42 \%$ [24]. Shi et al. (2013) investigated the potentiality of $\mathrm{CH}_{3} \mathrm{ONa}$ as a transesterification catalyst of waste chicken fat. Under the studied reaction conditions, the reported conversion of fat was 98.1\% [25]. Celante et al. (2018) achieved 99\% conversion of soybean oil using $\mathrm{CH}_{3} \mathrm{OK}$ catalyst [26]. Saponification and slow reaction rates are the major issues related to the homogeneous catalytic transesterification reactions. In order to secure appreciable reaction rates, the homogeneous catalyzed process requires high quality feedstocks, which must contain the free fatty acid (FFAs) level below 3\% by weight. Additionally, the presence of water in feedstock is cumbersome due to the hydrolysis of oils leading to FFAs which ultimately react with alkaline catalysts to produce undesirable soap formation [27]. In addition, during homogeneous catalytic transesterification, the postseparation treatment between the end-product biodiesel and glycerol needs lengthy processes and increases the cost of the end products [28-30].

The heterogeneous catalytic transesterification has several advantages over the homogeneous catalytic transesterification, including easy separation of biodiesel from glycerol, catalyst recycling/reuse, less energy requirement, and minimum consumption of water [21,31]. The solid catalyst to feedstock ratio is also significantly lower than that of the homogeneous catalyst to feedstock ratio. For example, 5.7 tons of solid supported $\mathrm{MgO}$ catalyst is enough to produce 100,000 tons of biodiesel [32] while 88 tons of $\mathrm{NaOH}$ is needed as catalyst for the production of 8000 tons of biodiesel [33]. In literature, the alkaline metal oxides such $\mathrm{CaO}$ [34] and $\mathrm{MgO}$ [35] are commonly used as solid phase catalyst for transesterification of bio-oils. The use of solid catalysts have been able to overcome a number of challenges of homogeneous catalysts for biodiesel production. Endalew et al. (2011) reported 
$\mathrm{CaO}$ and $\mathrm{Li}-\mathrm{CaO}$ as solid phase catalysts for esterification and transesterification of Jatropha curcas oil into biodiesel. The catalysts provided complete conversion of Jatropha curcas oil under mild reaction conditions, which also helped to maintain the activity of the catalysts for extended periods of time [36]. The transesterification of high fatty acid-containing Cerbera odollam was conducted using alumina-supported sulfated zirconia catalysts. The catalyst showed excellent tolerance of high fatty acid concentrations. The biodiesel yield was almost $83.8 \%$, which was significantly higher than that of traditional $\mathrm{NaOH}$ catalyst [37]. Viriya-empikul et al. (2012) investigated Ca-based solid catalysts derived from industrial waste for biodiesel production from palm oil [38]. Approximately 94.1\% biodiesel yield was achieved when the transesterification was carried out at $60^{\circ} \mathrm{C}$ for $2 \mathrm{~h}$.

The present review focuses on the use of solid base, acid, acid-base and biocatalysts for biodiesel production from microalgal oil as the reliable feedstock with comparison to other available feedstock. Furthermore, this review also highlights the suitable heterogeneous catalysts for biodiesel production from microalgae in terms of the yield of biodiesel, optimal reaction conditions, reusability of the catalyst, cost and environmental sustainability [39].

\section{Microalgae Oil as Feedstock for Biodiesel Production}

Microalgae has recently been documented as the most prospective feedstock for biodiesel production [40]. Microalgae are minute photosynthetic organisms that are located in a broad array of ecological settings, on water and land. It has been stated that utilization of microalgae for the production of biodiesel has a high return in terms of lipid content, biodiesel given per acre of farmland for a variety of crops and environmental sustainability [40], although the biodiesel (lipid) contents and its productivity significantly vary among the microalgae species [41].

Among numerous sorts of algae, microalgae appear to be resourceful because: (1) they have lofty increase rates; e.g., repetition in $24 \mathrm{~h} \mathrm{[42],} \mathrm{(2)} \mathrm{their} \mathrm{lipid} \mathrm{content} \mathrm{could} \mathrm{be} \mathrm{customized} \mathrm{through}$ shifting the growth medium composition [43], (3) they can be produced more than once a year [44], (4) saline or waste water could be used [44], (5) atmospheric $\mathrm{CO}_{2}$ is the carbon resource for the growth of microalgae [44], (6) biodiesel produced from algal lipid is nonhazardous and highly eco-friendly [44], (7) microalgae produce 15-300 times extra oil for biodiesel production than customary crops on a regional basis [45]. Predominantly, the microalgae have superior lipid production yields, which have been noticed between 58,000 L/ha to 136,000 L/ha [41].

Moreover, it has a much quicker growth rates than agricultural crops [46,47]. Comparatively, oil from oilseeds such as rapeseed or soybean present oil yields of $974 \mathrm{~L} /$ ha and $636 \mathrm{~L} / \mathrm{ha}$, respectively. It is noteworthy that the yield of transesterification reaction relies on the character of the lipids. The character of the lipids is vital data for biodiesel making because a number of microalgae can hold up to $93 \%$ (g/g lipid) of glycolipids and phospholipids [48]. In addition, microalgae also donate the value to the environment. These organisms can be capable of fastening $\mathrm{CO}_{2}$ from the atmosphere and thus make a payment to greenhouse gas (GHG) reduction.

Although there is a variety of advantages related with the making of biofuels by means of microalgae, the economic viability of the microalgae-based biofuel industry equivalent to that of either the petroleum or the bioethanol industry has not yet been attained. There is a solitary cause for the elevated production price of algal biofuels. This elevated manufacturing cost of algal biofuels is linked with the different techniques of downstream processing inherent in the production of biodiesel using microalgae [49].

Additionally, while biodiesel is thought to be the major accessible fuel produced from algae, other vital fuel preserves can also be produced, thus making utilization of algae more attractive. Algal oil can be used for producing different types of fuels like bio-gasoline, hydrogen, methane, and ethanol. The biomass-residue is appropriate as a viable feedstock for burning. Additional significant areas of use for algae consist of ecological organization. One variety of algal species possesses an outstanding bioremediation characteristic and consequently, appropriate for nutrient removal from wastewater. Furthermore, algae can be used to produce pigments and fertilizers effectively [50]. 


\section{Outline of Biodiesel Production Process from Microalgae}

All the current processes for biodiesel production from microalgae comprise a production phase where cells are raised, then separated from the maturing medium followed by lipid removal. Biodiesel or additional biofuels are then produced in a form similar to available processes and knowledge utilized for different biofuel feedstocks [51-53]. Figure 2 illustrates the process flow diagram for biodiesel production from microalgae.

For the processing of biodiesel from a variety of biological resources, transesterification, through a number of successive reversible reactions, is the frequent methodology: triglycerides are transformed stepwise to diglycerides, monoglycerides, and lastly glycerol, with the release of the fatty acid methyl ester distinct as biodiesel at every step in the process. In general, an alcohol and a catalyst are desirable for transesterification of triglycerides [54]. The fundamental reaction of transesterification is illustrated in Figure 3.

The transesterification reaction requires an appropriate catalyst to facilitate the logical conversion rates. The characteristics of the catalysts are important because the reaction situation and post treatment ladder are preset by the characteristic of the catalyst used. Traditionally, the majority of biodiesel is produced with alkaline catalysts, such as $\mathrm{NaOH}$ and $\mathrm{KOH}$, owing to their broad accessibility and low price. Although transesterification is practicable with catalysts of a base, the general homogeneous base-catalyzed procedure experiences severe restrictions which transform into increased production expenses intended for biodiesel. Stern feedstock provisions are a major concern with this procedure. The FFA content in the lipid feedstock should not exceed $0.5 \mathrm{wt} \%$, as the higher FFA content causes soap creation, which ultimately hampers fuel grade biodiesel production. FFAs in the feedstock react with metal hydroxide catalyst forming soap (Figure 4a). Gels, which increase viscosity can be raised due to soap formation which greatly increases the product separation cost [55].

Moreover, strict specifications must be followed during the choices of alcohol and catalyst. Total water content of alcohol and catalyst must be within the range of $0.1-0.3 \mathrm{wt} \%$ or less for keeping the anhydrous nature [56]. This anhydrous nature is mandatory because it is presumed that feedstock stimulates hydrolysis of the alkyl esters to FFAs in the presence of water (Figure $4 \mathrm{~b}$ ) and, as a result, the creation of soap. The feedstock requirements for base-catalyzed reactions have guided researchers to pursue catalytic and processing substitutes that could ease this complexity and reduce production costs. In this regard, the procedure of acid catalyzed reactions has the capability to overcome this difficulty since acid catalysts do not demonstrate significant vulnerability to FFAs. 


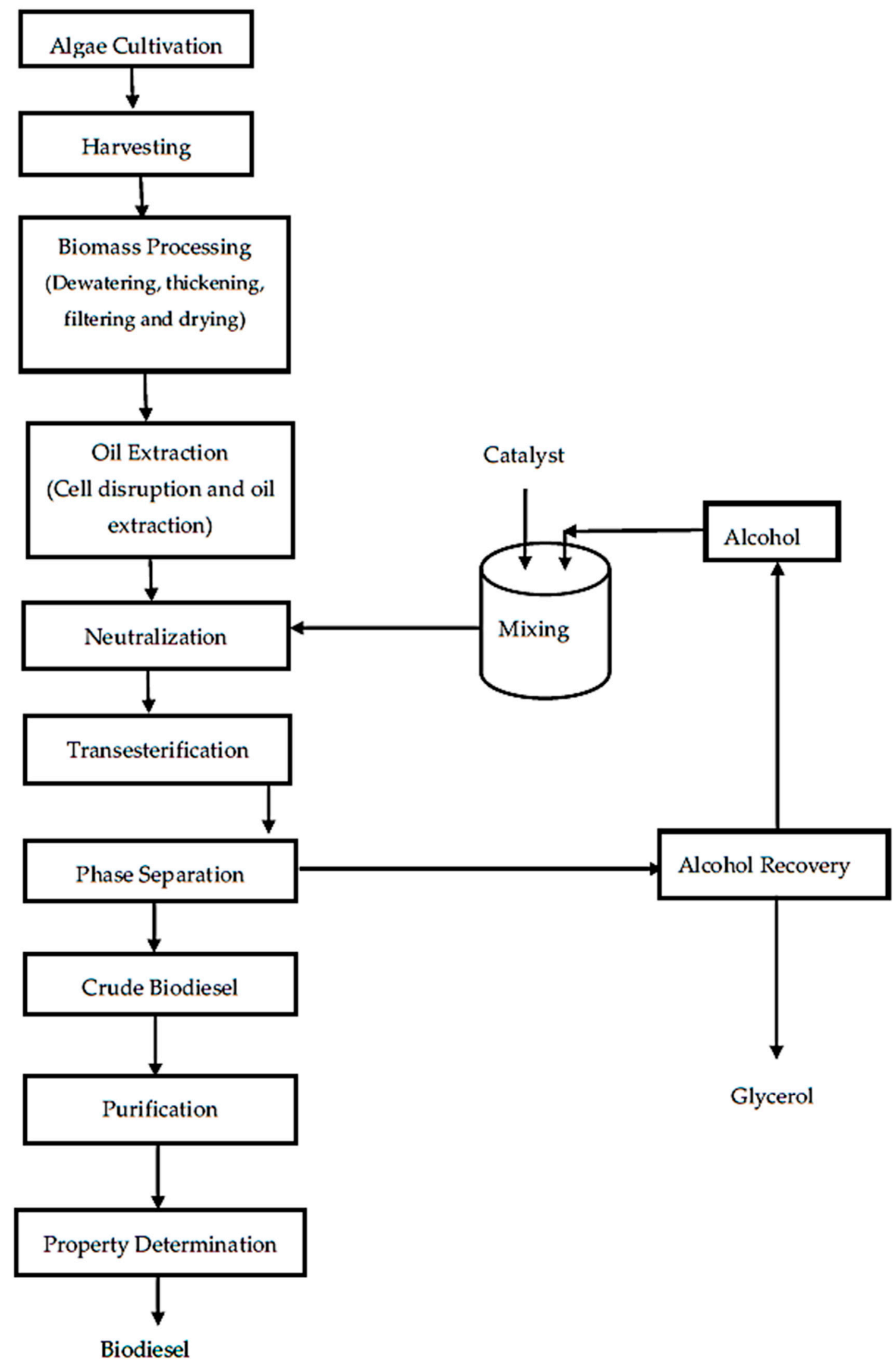

Figure 2. Flowchart of conventional biodiesel production from microalgae. 
<smiles>[R]C(=O)OCC(COC([R])[O-])OC([R])=O</smiles>

Triglyceride (TG)<smiles>[R]C(=O)OCC(O)OC([R])=O</smiles>

FAME

Diglyceride (DG)<smiles>[R3]C(=O)OC([O+])C(CO)OC([R])=O</smiles>

Diglyceride (DG)<smiles>[R16]C(=O)OC</smiles><smiles>[R3]C(=[O+])OCC(O)CO</smiles>

Monoglycerde (MG)

FAME

Glecerol (GL)

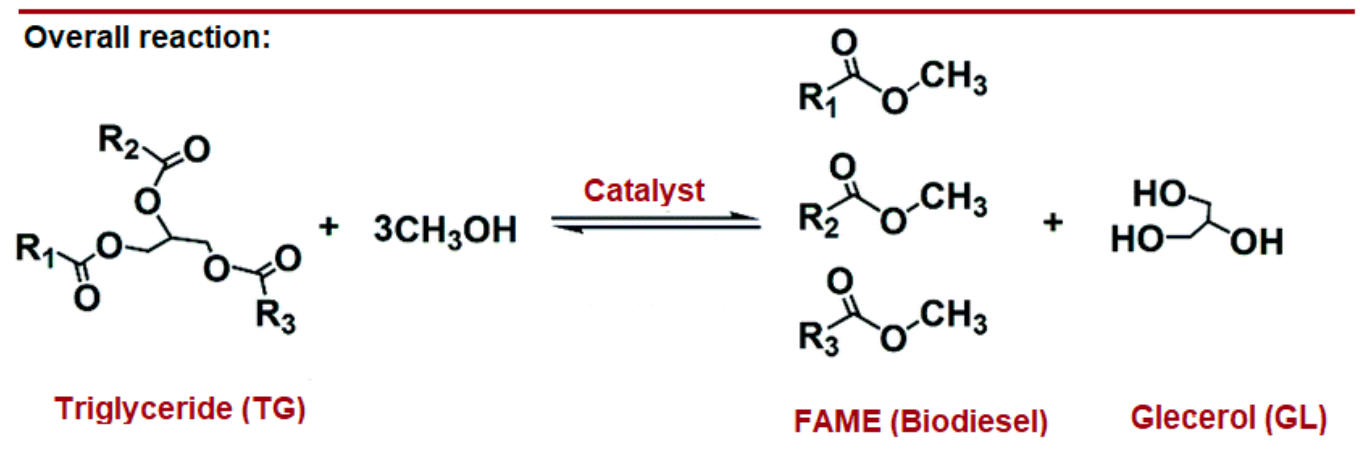

Figure 3. Transesterification reactions of glycerides with methanol.

a)

$\mathrm{RCOOH}+\mathrm{NaOH}\left(\right.$ or $\left.\mathrm{CH}_{3}-\mathrm{ONa}\right)$

RCOONa

$+\mathrm{H}_{2} \mathrm{O}\left(\right.$ or $\left.\mathrm{CH}_{3}-\mathrm{OH}\right)$

Soap

Base Catalyst

b) $\mathrm{RCOOCH}_{3}+\mathrm{H}_{2} \mathrm{O}$

$\mathrm{RCOOH}+\mathrm{CH}_{3}-\mathrm{OH}$

Figure 4. (a) Base catalyst reaction with FFAs to make soap and water, both unwanted byproducts. (b) Water supports the creation of FFAs. These, then, can neutralize the catalyst and generate soap, as in (a).

In addition, Diasakou et al. [57] has also stated that the transesterification reaction usually occurred in three steps where triglyceride (TG) reacted with methanol to produce diglycerides (DG), after that diglycerides (DG) again reacted with methanol to produce monoglycerides (MG) and lastly reacted with methanol to yield methyl ester and glycerol (Figure 3). Moreover, Kusdiana et al. [58] recommended a one-step version for the transesterification reactions (as shown in overall reaction in Figure 3). If we consider alcohol, triglycerides, alkyl ester and glycerol as AL, TG, AE, GL are accordingly, Thus, the overall reaction can be presented as:

$$
\mathrm{TG}+3 \mathrm{AL} \rightarrow \mathrm{GL}+3 \mathrm{RE}
$$


The rate of reaction of the above equation can be offered by the following rate expression

$$
\text { Rate }=-\frac{d(T G)}{d t}
$$

where $T G$ refers to the substance of non-edible oil utilized in that study. In that supercritical alcohol method, three species were well-defined as unalkyl esterified compounds $\left(U_{a e}\right)$, alkyl esters and glycerol. Unalkyl esterified compounds $\left(U_{a e}\right)$ which comprise monoglycerides, diglycerides, triglycerides, and unreacted FFA. Thus, above rate expression can be modified as [58]:

$$
\text { Rate }=-\frac{d\left(U_{a e}\right)}{d t}
$$

Commonly, the overall reaction rate is articulated in the Arrhenius form as:

$$
-\frac{d\left(U_{a e}\right)}{d t}=\mathrm{A} \exp \left(-\frac{E}{R T}\right)\left(U_{\mathrm{ae}}\right)^{\mathrm{n}}(A L)^{\mathrm{m}}
$$

The entire reaction is presumed to proceed as first order reaction.

Although homogeneous catalysts are more effective, they can create severe contamination problems that ultimately demand better separation and product purification conventions, which turn into elevated biodiesel production costs as well as feedstock costs. To be economically feasible and to compete commercially with petroleum-based diesel fuel, the synthesis of biodiesel processing needs as few reaction steps as possible and to reduce the number of separation steps. In this context, the use of a vigorous heterogeneous (solid) catalyst is preferable, along with a cost-effective nonedible oil like micro algal oil could be well suited.

A broad variety of catalysts (homogeneous/heterogeneous) can be utilized to produce biodiesel from various raw materials as shown in Figure 5. It is noteworthy that in comparison to homogeneous catalysis, heterogeneous catalysis has been considered as the top option for biodiesel knowledge in the near future. Heterogeneous catalysts can simply be recycled, recovered, and possess environmentally benign behaviors. Nowadays, heterogeneous catalysts have been employed for biodiesel production from nonedible oil and received global interest owing to their outstanding performance. Currently, it is interesting that some of the heterogeneous catalysts can execute concomitant esterification of free fatty acids and transesterification of the triglycerides available within the nonedible oil effectively.

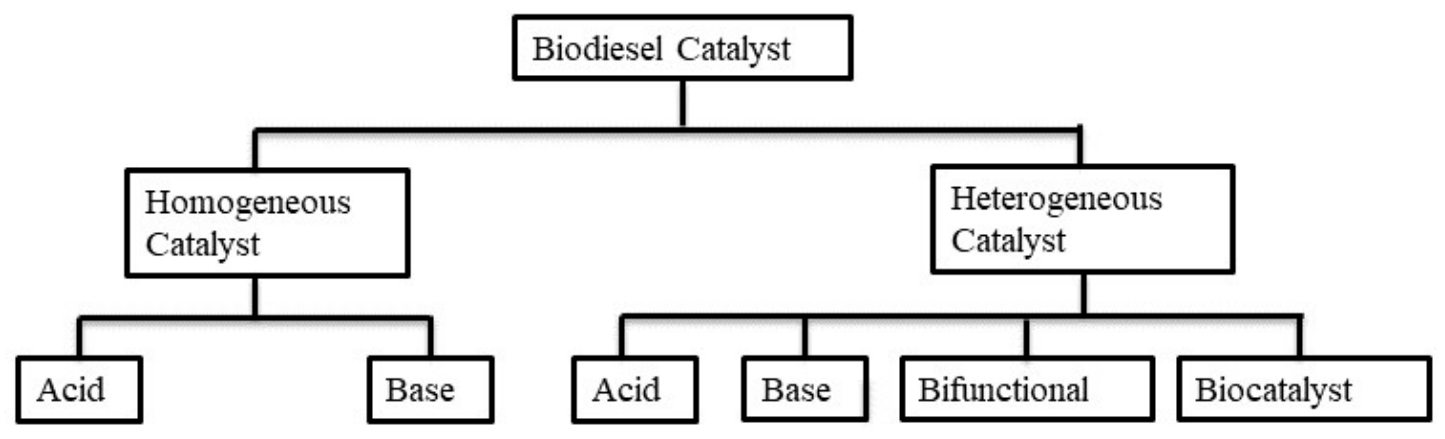

Figure 5. Catalysts used for biodiesel production.

\section{Heterogeneous Catalysts for Biodiesel Production}

Compared to the homogeneous catalyst, heterogeneous catalysts, which usually appear in solid form, act at a different phase in the reaction mixture of liquid. The homogeneous catalyst is broadly employed in the biofuel industry due to its several advantages, such as high reaction rate, short process time, high accessibility of catalysts [59]. On the contrary, the use of the homogeneous catalyst in esterification and transesterification reactions creates a number of difficulties such as high-cost 
post separation processes. To overcome the different problems associated with the utilization of homogeneous bases and liquid acids such as alcoholysis catalysts, many findings were stated to investigate the actions of a variety of heterogeneous materials [50]. Tables 1 and 2 present a list of various solid bases and acid catalysts, respectively, recognized for biodiesel production.

Processing costs can be reduced significantly through the utilization of heterogeneous catalyst because it can be simply recovered, separated and use again [60]. The pivotal features of heterogeneous catalysts are its tuning characteristics that create acidic-basicity, porosity and surface area that can greatly increase the wide range of feedstock for esterification/transesterification process. No additional pretreatment is required for the reduction of the FFA content while using heterogeneous catalysts [61]. Moreover, this can simply catalyze the biodiesel production from high acid oil. Various features of the heterogeneous catalysts (solid acid, solid base, acid-base and biocatalyst) are well studied in this review as each one retains a distinct property to the process.

\subsection{Basic Solid Catalysts}

Base catalysts are especially appropriate for good purity oils with low FFA contents because they are more vigorous than acids in transesterification. Continuous flow and a packed bed arrangement are generally employed for synthesizing biodiesel using solid base catalyst which ultimately facilitate both coproduction of glycerol with good purity and catalyst separation, thus lessening the production cost and promoting the use of the catalyst again. Supported alkali metals, alkali or alkaline earth oxides, basic zeolites, immobilized organic bases and clays such as hydrotalcites are known as various solid base catalysts [62].

Solid bases, meaning primarily solids with the Brønsted basic and Lewis basic activity centers, that can provide electrons (or accept protons) for (or from) reactants. Synthesis of biodiesel has been carried out intensively over the last ten years through heterogeneous base-catalyzed transesterification using low-qualified oil or fat with FFAs and water. The catalytic efficacy of traditional heterogeneous base catalysts is comparatively minimal and demands to be enhanced. Different sorts of catalytic materials have been tested to enhance the transesterification of glycerides. The commonly studied solid material-based catalysts include hydrotalcites, metal oxides, metallic salt, supported base catalyst and zeolites. As mentioned previously, reactions concerning heterogeneous bases proceed by reactions of either the Lewis or the Brønsted basic sites of the catalyst with a monohydric alcohol (typically ethanol or methanol). The produced alkoxide mixture interacts with triglyceride ester in the oil to yield biodiesel and glycerol in the following steps. Figure 6 shows the mechanism of base-catalyzed transesterification. Solid basic catalysts such as, $\mathrm{ZnO}, \mathrm{CuO}$, zeolites, $\mathrm{CaO}, \mathrm{SrO}, \mathrm{MgO}, \mathrm{BaO}$, basic polymers and carbonates such as $\mathrm{MgCO}_{3}, \mathrm{CaCO}_{3}, \mathrm{BaCO}_{3}$ and $\mathrm{SrCO}_{3}$ have drawn interest as heterogeneous transesterification catalysts.

\subsection{1. $\mathrm{MgO}$ as a Base Heterogeneous Catalyst}

Derivatives of alkaline earth metals and oxides such as $\mathrm{Ba}, \mathrm{Be}, \mathrm{Ca}, \mathrm{Mg}$, $\mathrm{Ra}$, and $\mathrm{Sr}$ are applied by various investigators. $\mathrm{SrO}$ and $\mathrm{MgO}$ are broadly utilized along with the other alkaline earth metals, which have a decent heterogeneous character as a catalyst for biodiesel production $[63,64]$. Eighteen percent conversion from triacetin feedstock was found for an $8 \mathrm{~h}$ reaction time with $600{ }^{\circ} \mathrm{C}$ calcination temperature when $\mathrm{MgO}$ was utilized as a catalyst by Lopez et al. [65]. This lower amount of conversion is owing to the minimal surface area of the catalyst. In recent times, Di serio et al. [66] used $\mathrm{MgO}$ catalyst and noted a $92 \%$ biodiesel yield with $5.0 \mathrm{wt} \%$ of the catalyst in $1 \mathrm{~h}$, applying a 12:1 methanol to oil molar ratio. Dossin et al. [32] investigated that $\mathrm{MgO}$ has the capability to produce five hundred tons of biodiesel in batch reactors through transesterification reaction while maintaining the ambient temperature. Biodiesel manufacture cost is decreased in batch reactors owing to the application of ambient temperatures. Some researchers have revealed that $\mathrm{MgO}$ catalyst can give $91 \%$ fatty acid methyl ester (FAME) yield in supercritical conditions $\left(300^{\circ} \mathrm{C}\right)$ as well as at a high methanol to oil molar ratio (39.6:1) [66]. 


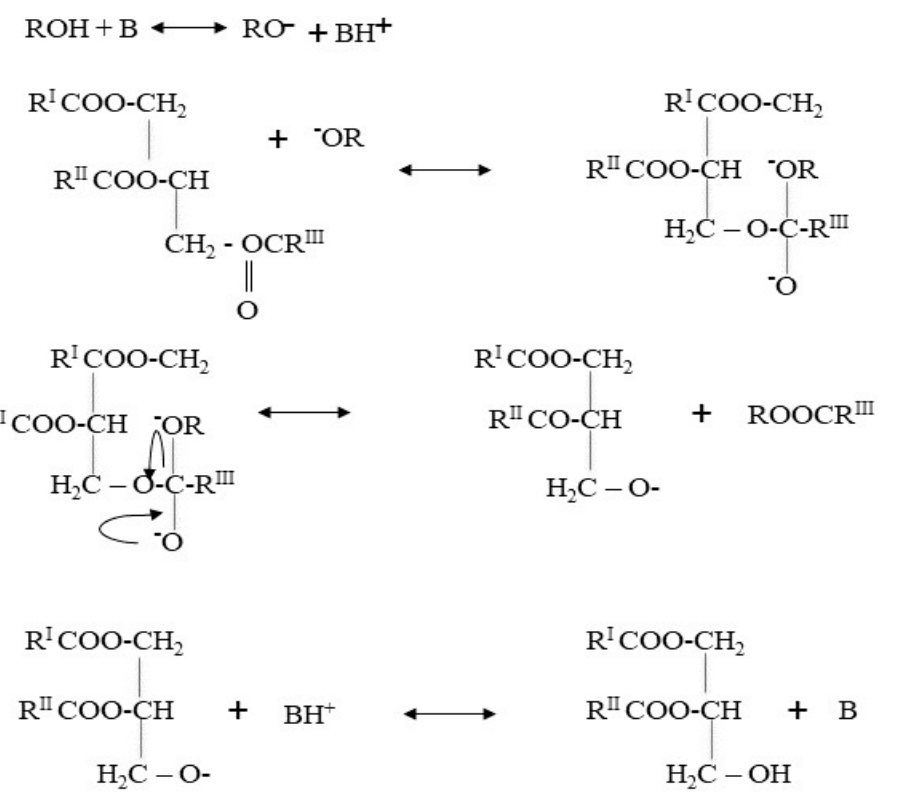

Figure 6. Mechanism of base-catalyzed transesterification.

\subsection{2. $\mathrm{CaO}$ as a Base Heterogeneous Catalyst}

Biodiesel has been produced from soya bean oil by Liu et al. [67] utilizing $\mathrm{CaO}$ as the solid base catalyst. He reported some merits of $\mathrm{CaO}$ as a solid base catalyst such as lengthening the catalyst's life, high activity and moderate reaction conditions. Nowadays, calcium oxide $(\mathrm{CaO})$ as a heterogeneous catalyst received the attention of the researcher owing to its relatively lower production cost $[59,68]$ and its high basic nature [69]. Liu et al. [67] received ninety five percent conversion of the oil to the ester through transesterification reaction utilizing $8 \%$ of $\mathrm{CaO}$ with respect to oil mass and a reaction time of three hours, as well as a methanol to oil molar ratio of 12:1. Viola et al. achieved $93 \%$ conversion with the same reaction utilizing $\mathrm{CaO}$ as the catalyst with $80 \mathrm{~min}$ reaction time and $65^{\circ} \mathrm{C}$ reaction temperature and applying 5\% catalyst with regard to oil and methanol to oil molar ratio of $6: 1$ [70]. Zhu et al. [71] used a solution of $\mathrm{CaO}$ with ammonium carbonate for the conversion of Jatropha curcas oil and found 93\% conversion. Colombo et al. [34] employed recycling reactors to enhance the production of biodiesel from vegetable oil using $\mathrm{CaO}$ as a heterogeneous catalyst. They reported suitable reaction conditions as a 75 min reaction time, a methanol to oil molar ratio of $6: 1$, and a $3 \%$ catalyst mass with respect to oil mass for one hundred percent biodiesel production.

Veljkovic et al. [69] noted the methanolysis of sunflower oil using $\mathrm{CaO}$ as a heterogeneous catalyst when applying a $550{ }^{\circ} \mathrm{C}$ calcination temperature. They employed $1 \mathrm{wt} \%$ catalyst based on oil weight and maintained a two-hour reaction time at $60{ }^{\circ} \mathrm{C}$ temperature and found a $98 \%$ yield with a $6: 1 \mathrm{M}$ ratio of sunflower oil to methanol during transesterification reaction.

Kawashima et al. [72] applied the $\mathrm{CaO}$ as heterogeneous catalyst for biodiesel production from rapeseed oil through the transesterification reaction. They treated the $\mathrm{CaO}$ in a different way. First, they activated the $\mathrm{CaO}$ by a pretreatment with methanol at $25^{\circ} \mathrm{C}$ for $1.5 \mathrm{~h}$. In this way, a small amount of $\mathrm{CaO}$ could be transferred into $\mathrm{Ca}\left(\mathrm{OCH}_{3}\right)_{2}$, which has superior catalytic activity than nonactivated $\mathrm{CaO}$. Later, the $\mathrm{Ca}\left(\mathrm{OCH}_{3}\right)_{2}$ was utilized to produce FAME and glycerin from rapeseed oil.

Likewise, $\mathrm{CaO}$ and modified $\mathrm{CaO}$ with $\mathrm{Li}$ were studied by Puna et al. [73] to produce biodiesel. They received better catalytic activity as well as stability for both catalysts. In fact, more than $92 \%$ biodiesel yields were achieved employing two consecutive batch reactions. Thus, the catalysts are appropriate for the production of biodiesel. 


\subsection{3. $\mathrm{SrO}$ as a Base Heterogeneous Catalyst}

Soybean oil was utilized by Liu et al. [74] for transesterification reactions, utilizing SrO metal oxides as a base heterogeneous catalyst. Calcination of $\mathrm{SrCO}_{3}$ was done at $1200{ }^{\circ} \mathrm{C}$ for $5 \mathrm{~h}$ for the preparation of the catalyst. Brunauer-Emmett-Teller (BET) surface area and robust basicity were found to be $1.05 \mathrm{~m}^{2} / \mathrm{g}$ and $\mathrm{H}_{-}=26.5$, respectively, from this $\mathrm{SrO}$ catalyst. The transesterification reaction was done at $65{ }^{\circ} \mathrm{C}$ temperature for $30 \mathrm{~min}$ reaction time and obtained $95 \%$ biodiesel yield. Moreover, $3 \mathrm{wt} \%$ catalyst content and 12:1 molar ratio of methanol to oil was maintained during this reaction. Later, a slight reduction in biodiesel yield was observed for 10 cycles repeated use of SrO catalyst. Figure 7 portrayed the reaction mechanisms as presented by authors. SrO with methanol forms an ionic complex during the major reaction step.

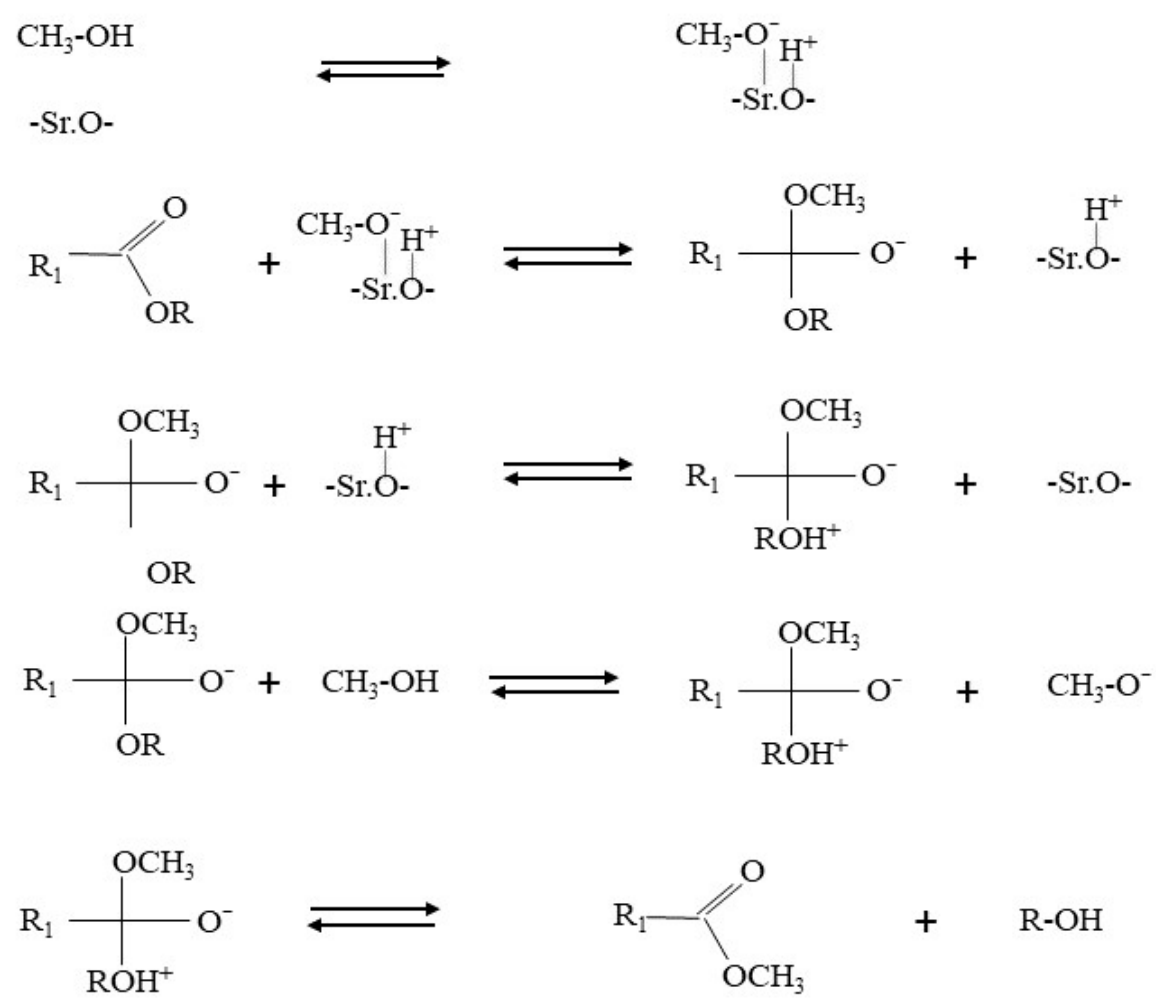

Figure 7. Mechanism of SrO catalyst transesterification.

\subsubsection{Biodiesel Production with Mixed Metal Oxide and Derivatives}

Two or more metal oxides are generally used to produce a solid mixed-metal-oxide catalyst. The basic concept behind the preparation of solid mixed-metal-oxide catalysts was to increase surface area, augment the basic or acid strength, and improve the stability of these catalysts with respect to single metal oxide.

$\mathrm{CaO}$ or $\mathrm{MgO}$ are commonly doped with base mixed-metal-oxide to increase their catalytic activity. Catalysts with these types reveal the superior activity during the transesterification reaction in biodiesel production. The presence of a certain amount of free fatty acids (FFA) in the raw material such as oils or fats are thought to be mandatory; if not it can create base catalyst poisoning which ultimately reduces the biodiesel quality [61].

Sol-gel techniques were utilized to prepare the $\mathrm{MgO}-\mathrm{Al}_{2} \mathrm{O}_{3}$ and $\mathrm{CaO}-\mathrm{Al}_{2} \mathrm{O}_{3}$ catalysts. These catalysts were found to be efficient during the transesterification of lipids from the microalgae Nannochloropsis oculate and achieved $97.5 \%$ biodiesel yield at $50{ }^{\circ} \mathrm{C}$ reaction temperature and $6: 1$ methanol-oil ratio [75]. CaO- $\mathrm{Al}_{2} \mathrm{O}_{3}(80 \mathrm{wt} \%)$ was the more active catalyst among these two prepared catalysts and could be recycled at least twice. It was anticipated that the sol-gel synthesis would promote the comparatively high basic strength and site density in the catalysts that would make the 
catalysts more reactive and stable. Zabeti et al. (2010) [76] produced a mesoporous $\mathrm{CaO} / \mathrm{Al}_{2} \mathrm{O}_{3}$ catalyst for biodiesel production from palm oil. They received $98.64 \%$ high methyl ester while maintaining an optimized reaction temperature. The optimization was done by applying central composite design (CCD) and response surface methodology (RSM). A large surface area and strong basic sites of the catalyst are considered pivotal factors for high reactivity of catalysts.

Similarly, different investigations were also carried out to alter the characteristics of $\mathrm{MgO}$-based catalysts. For instance, sol-gel technique was applied to produce a sequence of $\mathrm{TiO}_{2}-\mathrm{MgO}$ mixed oxide catalysts and was found to be more efficient for biodiesel production from waste cooking oil, having an acid value of $3.6 \mathrm{mg} \mathrm{KOH} \mathrm{g}^{-1}$. A $5 \mathrm{wt} \% \mathrm{TiO}_{2}-\mathrm{MgO}$ catalyst calcined at $650{ }^{\circ} \mathrm{C}$ having a $\mathrm{Mg} / \mathrm{Ti}$ molar ratio of 1 for $6 \mathrm{~h}$ reaction time at $150{ }^{\circ} \mathrm{C}$ was employed and achieved more than $85 \%$ FAME yield while maintaining a 30:1 methanol to oil molar ratio [77]. The authors stated that the incorporation of a $\mathrm{Ti}$ ion reinforced the catalyst stability due to the defects promoted by the replacement of Ti ions for Mg ions. They received consistently better catalytic activity in terms of FAME yield even after four times recycling. Another study applied a coprecipitation method to produce a $\mathrm{Mg}-\mathrm{Zr}$ solid base catalyst having $2: 1 \mathrm{Mg} / \mathrm{Zr}$ mass ratio. They calcined the catalyst for four hours at $650{ }^{\circ} \mathrm{C}$. Finally, the obtained catalysts were utilized to produce biodiesel from microalgae Nannochloropsis oculate through one-pot transesterification [78].

\subsubsection{Biodiesel Production with Transition Metal Oxides and Derivatives}

The transesterification rate of solid bases is commonly superior to that of solid acids. Thus, a variety of transition metal oxides with different Lewis properties were tested to produce biodiesel. $\mathrm{TiO}_{2}$ and $\mathrm{MnO}$ are moderate bases revealing better catalytic activity for the production of biodiesel [79]. These catalysts were applied to low grade feedstock having up to $15 \%$ high FFA content for the concomitant transesterification of triglycerides and esterification of FFAs while maintaining continuous flow conditions. As a result, in the presence of high FFA, the soap formation associated with metal leaching from the surface of the catalyst was reduced significantly compared to that of traditional base homogeneous catalysts.

\subsubsection{Waste Material-Based Heterogeneous Catalysts}

Currently, the preparation of heterogeneous catalysts from both biological resources and industrial waste have received attention due to their low cost and good efficiency. These types of natural resources or waste material-derived heterogeneous catalysts showed effectiveness during the transesterification of various oils for biodiesel production. In addition, some authors noted that heterogeneous catalysts obtained from renewable resources revealed their capacity as cost-effective catalysts to produce biodiesel. Table 1 summarizes the commonly investigated basic materials as solid catalysts for transesterification reactions.

Deka et al. [80] obtained a new catalyst from the trunk of Musa balbisiana Colla (one variety of banana plant) and utilized it for the conversion of Thevetia peruviana seed oil to biodiesel. They achieved $96 \%$ conversion of oil to biodiesel using $20 \mathrm{wt} \%$ catalyst while maintaining a three-hour reaction time at $32{ }^{\circ} \mathrm{C}$ temperature. The catalyst can simply be derived from the waste of harvested banana plants and acts as heterogeneous catalyst. It was noted that after every recycle, catalyst efficiency was reduced successively. Spectroscopic and chemical observation revealed the existence of $\mathrm{Cl}^{-}, \mathrm{CO}_{3}{ }^{2-}, \mathrm{K}^{+}$and $\mathrm{Na}^{+}$as the main components with other relevant metals in ppm level such as $\mathrm{Ni}, \mathrm{Cr}, \mathrm{Mn}, \mathrm{Al}, \mathrm{Fe}, \mathrm{Cu}, \mathrm{V}$, $\mathrm{Pd}$, and $\mathrm{Cd}$. The metals are existing as their oxides, carbonates or chlorides. The surface area of the catalyst was determined using BET technique and found at $1.487 \mathrm{~m}^{2} / \mathrm{g}$. 
Table 1. Catalysts utilized as basic solids for transesterification reaction.

\begin{tabular}{|c|c|c|c|c|c|c|c|}
\hline \multirow[b]{2}{*}{ Catalyst } & \multirow[b]{2}{*}{ Feedstock } & \multicolumn{4}{|c|}{ Optimum Reaction Conditions } & \multirow[b]{2}{*}{$\begin{array}{l}\text { Biodiesel } \\
\text { Yield }\end{array}$} & \multirow[b]{2}{*}{ Reference } \\
\hline & & Temp. & Time & Methanol/Oil & $\begin{array}{l}\text { Catalyst } \\
\text { Amount }\end{array}$ & & \\
\hline $\begin{array}{l}\mathrm{CaO} \text { from } \\
\text { eggshells }\end{array}$ & Palm oil & $65^{\circ} \mathrm{C}$ & $2 \mathrm{~h}$ & $12: 1$ & $1.5 \mathrm{wt} \%$ & $98 \%$ & [81] \\
\hline $\mathrm{CaO}$ & $\begin{array}{l}\text { Sunflower } \\
\text { oil }\end{array}$ & $80^{\circ} \mathrm{C}$ & $5.5 \mathrm{~h}$ & $6: 1$ & $1 \mathrm{wt} \%$ & $91 \%$ & [82] \\
\hline $\begin{array}{l}\mathrm{KNO}_{3} \\
/ \mathrm{CaO}\end{array}$ & Rapeseed oil & $65^{\circ} \mathrm{C}$ & $3 \mathrm{~h}$ & $6: 1$ & $1 \mathrm{wt} \%$ & $98 \%$ & [83] \\
\hline $\mathrm{CaO} / \mathrm{Al}_{2} \mathrm{O}_{3}$ & Palm oil & $64.29^{\circ} \mathrm{C}$ & $5 \mathrm{~h}$ & $12.14: 1$ & $5.97 w t \%$ & $98.64 \%$ & {$[76]$} \\
\hline $\mathrm{CaO} / \mathrm{Fe}_{3} \mathrm{O}_{4}$ & $\begin{array}{l}\text { Jatropha } \\
\text { curcas oil }\end{array}$ & $70^{\circ} \mathrm{C}$ & $1.3 \mathrm{~h}$ & $15: 1$ & $2 \mathrm{wt} \%$ & $95 \%$ & [84] \\
\hline $\mathrm{Li} / \mathrm{MgO}$ & Soybean oil & $60{ }^{\circ} \mathrm{C}$ & $2 \mathrm{~h}$ & $12: 1$ & $9 w \mathrm{t} \%$ & $93.9 \%$ & [85] \\
\hline $\mathrm{KOH} / \mathrm{MgO}$ & Mutton fat & $65^{\circ} \mathrm{C}$ & $0.3 \mathrm{~h}$ & $22: 1$ & $4 \mathrm{wt} \%$ & $98 \%$ & {$[86]$} \\
\hline Dolomite & $\begin{array}{l}\text { Palm kernel } \\
\text { oil }\end{array}$ & $60^{\circ} \mathrm{C}$ & $3 \mathrm{~h}$ & $30: 1$ & $6 \mathrm{wt} \%$ & $98 \%$ & [87] \\
\hline Dolomite & Canola oil & $67.5^{\circ} \mathrm{C}$ & $3 \mathrm{~h}$ & $6: 1$ & $3 w t \%$ & $91.78 \%$ & [88] \\
\hline $\begin{array}{l}\mathrm{CaMgO} \text { and } \\
\mathrm{CaZnO}\end{array}$ & $\begin{array}{l}\text { Jatropha } \\
\text { curcas oil }\end{array}$ & $65^{\circ} \mathrm{C}$ & $6 \mathrm{~h}$ & $15: 1$ & $4 \mathrm{wt} \%$ & $80 \%$ & [89] \\
\hline $\begin{array}{c}\mathrm{KF} / \mathrm{Ca}-\mathrm{Al} \\
\text { hydrotalcite }\end{array}$ & Palm oil & $65^{\circ} \mathrm{C}$ & $5 \mathrm{~h}$ & $12: 1$ & $5 \mathrm{wt} \%$ & $97.98 \%$ & [90] \\
\hline $\begin{array}{c}\mathrm{Mg}-\mathrm{Al} \\
\text { hydrotalcite }\end{array}$ & Soybean oil & $230^{\circ} \mathrm{C}$ & $1 \mathrm{~h}$ & $13: 5$ & $5 \mathrm{wt} \%$ & $90 \%$ & [91] \\
\hline $\begin{array}{c}\text { Mg-Al } \\
\text { hydrotalcite }\end{array}$ & Jatropha oil & $45^{\circ} \mathrm{C}$ & $1.5 \mathrm{~h}$ & $4: 1$ & $1 \mathrm{wt} \%$ & $95.2 \%$ & [92] \\
\hline $\begin{array}{c}\mathrm{CaO} / \text { mesoporous } \\
\text { silica }\end{array}$ & Soybean oil & $60^{\circ} \mathrm{C}$ & $8 \mathrm{~h}$ & $16: 1$ & $5 w t \%$ & $95.2 \%$ & [93] \\
\hline Sodium silicate & Soybean oil & $60^{\circ} \mathrm{C}$ & $1 \mathrm{~h}$ & $7.5: 1$ & $3 \mathrm{wt} \%$ & $\approx 100 \%$ & [94] \\
\hline
\end{tabular}

Boro et al. [95] used the waste shells of Turbonilla striatula to obtain a solid oxide catalyst and applied it as a renewable heterogeneous catalyst for the conversion of mustard oil to biodiesel. The calcination temperature ranged from 600 to $900{ }^{\circ} \mathrm{C}$ for four hours during the preparation of catalyst from the shells and solid $\mathrm{CaO}$ formed at $800{ }^{\circ} \mathrm{C}$. It is noted that $93.3 \%$ biodiesel yield was achieved from the transesterification of mustard oil using $3 \mathrm{wt} \%$ catalyst maintaining 9:1 methanol to oil ratio for a six-hour reaction time at $65 \pm 5{ }^{\circ} \mathrm{C}$ temperature. The catalyst obtained from the waste shells of Turbonilla striatula can be used repeatedly considering gradual loss of catalytic activity during the transesterification of mustard oil.

Wei et al. [96] used waste eggshells for deriving a cost-effective solid catalyst. They calcined the catalyst at $1000{ }^{\circ} \mathrm{C}$ and utilized it to produce biodiesel from soybean oil and found good catalytic performance. The transesterification of soybean oil was carried out with 9:1 methanol to oil molar ratio using $3 \mathrm{wt} \%$ catalyst and maintaining the reaction temperature at $65^{\circ} \mathrm{C}$ for three hours. More than $95 \%$ biodiesel was achieved during this transesterification reaction. The catalyst obtained from the eggshell was applied repeatedly during the transesterification reaction and showed no significant loss of catalytic activity until 13 cycles.

\subsection{Acidic Solid Catalysts}

Acid catalysts express a greater tolerance to FFAs and water than basic homogeneous catalysts such as $\mathrm{NaOH}$ and $\mathrm{KOH}$. They have the potential to catalyze both esterification and transesterification concomitantly. It is evident that the reaction with homogeneous acid catalysts are relatively four thousand times slower than that of homogeneous base catalysts [97]. On the other hand, heterogeneous acid catalysts are suitable for low grade feedstocks having high FFAs but showing less catalytic activity. Solid acids can convert low grade fats or oils to biodiesel while maintaining the stable performance of catalysts.

Besides, solid acid catalysts are reactive catalysts for the esterification of FFA to maintain moderate condition before the transesterification reaction. Hence, a pretreatment step using homogeneous 
acid catalysts can be avoided. Solid acid catalysts are environmentally friendly and attain the necessary specifications of American Society for Testing Materials (ASTM) standards in produced biodiesel [98]. The solid acid catalyst needs extended time to attain highest conversion rate due to its lower catalytic activity [99].

Few works were stated on heterogeneous acid catalysts as compared to heterogeneous base catalysts. As presented in Table 2, there are different types of solid acid catalysts used in transesterification and esterification reactions comprising sulphonated saccharides, tungsten oxides, sulphonated zirconia (SZ), and Nafionl resins [100]. Muthu et al. [101] utilized sulphated zirconia as a solid acid heterogeneous catalyst for biodiesel production from Neem oil and found 95\% biodiesel yield maintaining 9:1 methanol to oil ratio. Shu et al. [102] achieved 94.8\% biodiesel yield from waste vegetable oil utilizing carbon-depending solid acid catalyst. Brucato et al. [103] found a $65 \%$ biodiesel yield from rapeseed with 40:1 methanol to oil ratio applying a heterogeneous acid catalyst-like titanium-doped amorphous zirconia.

Due to the presence of acid sites with different strengths of Bronsted or Lewis acidity in heterogeneous acid catalysts, industrially it has been considered more effective as contrast to homogeneous acid catalysts. Nafion-NR50, tungstated zirconia and sulphated zirconia are known as solid acid catalysts having enough acid site strength and are particularly preferable as catalysts during the transesterification reaction for biodiesel production [17]. Sulfur containing heterogeneous acid catalysts was investigated by other researchers for transferring acidic oils to biodiesel because sulfur-based acidic homogeneous catalysts like $\mathrm{H}_{2} \mathrm{SO}_{4}$ revealed a superior acceptance to water and FFA than that of basic homogeneous catalysts $(\mathrm{NaOH}$ and $\mathrm{KOH})$, proposing that these catalysts might be best effective for the processing of acidic oils [104].

Zeolites, sulphated zirconia, mixed metal oxides and ion exchange resins were studied by Kiss et al. [105] during esterification reactions. Among them, sulphated zirconia showed higher catalytic activity for esterification reaction. Park et al. [106] applied the sulphated zirconia $\left(\mathrm{SO}_{4}{ }^{2-} / \mathrm{ZrO}_{2}\right)$ and tungstated zirconia $\left(\mathrm{WO}_{3} / \mathrm{ZrO}_{2}\right)$ as heterogeneous acid catalysts for effective transfer of the FFA to FAME before the production of biodiesel. Tungstated zirconia $\left(\mathrm{WO}_{3} / \mathrm{ZrO}_{2}\right)$ is a pellet-type catalyst and was applied for an extended reaction time of $140 \mathrm{~h}$ at $75{ }^{\circ} \mathrm{C}$ and achieved $65 \%$ conversion.

Table 2. Acidic solids as catalysts for transesterification reaction.

\begin{tabular}{|c|c|c|c|c|c|c|c|}
\hline \multirow[b]{2}{*}{ Catalyst } & \multirow[b]{2}{*}{ Feedstock } & \multicolumn{4}{|c|}{ Optimum Reaction Conditions } & \multirow[b]{2}{*}{$\begin{array}{l}\text { Biodiesel } \\
\text { Yield }\end{array}$} & \multirow[b]{2}{*}{ Reference } \\
\hline & & Temp & Time & Methanol/Oil & $\begin{array}{l}\text { Catalyst } \\
\text { Amount }\end{array}$ & & \\
\hline $\begin{array}{c}\mathrm{SO}_{4}{ }^{2-} / \mathrm{TiO}_{2-}{ }^{-} \\
\mathrm{SiO}_{2}\end{array}$ & $\begin{array}{c}\text { Acidified } \\
\text { cottonseed oil }\end{array}$ & $200^{\circ} \mathrm{C}$ & $6 \mathrm{~h}$ & $9: 1$ & $3 w t \%$ & $92 \%$ & [107] \\
\hline $\mathrm{SO}_{4}{ }^{2-} / \mathrm{ZrO}$ & $\begin{array}{l}\text { Cerberra } \\
\text { odollam }\end{array}$ & $180^{\circ} \mathrm{C}$ & $3 \mathrm{~h}$ & $8: 1$ & $6 w t \%$ & $84 \%$ & [37] \\
\hline $\begin{array}{c}\mathrm{SO}_{4}{ }^{2-} / \mathrm{SnO}^{2-}- \\
\mathrm{SiO}_{2}\end{array}$ & Jatropha curcas & $180^{\circ} \mathrm{C}$ & $2 \mathrm{~h}$ & $15: 1$ & $3 w t \%$ & $97 \%$ & [108] \\
\hline $\begin{array}{c}\mathrm{SO}_{4}{ }^{2-} / \mathrm{SnO}^{2-}- \\
\mathrm{SiO}_{2}\end{array}$ & Moringa oleifera & $150^{\circ} \mathrm{C}$ & $2.5 \mathrm{~h}$ & $5: 1$ & $3 w t \%$ & $84 \%$ & [109] \\
\hline $\begin{array}{c}\mathrm{SO}_{4}{ }^{2-} / \mathrm{SnO}^{2-}- \\
\mathrm{SiO}_{2}\end{array}$ & $\begin{array}{l}\text { Croton } \\
\text { megalocarpus }\end{array}$ & $180^{\circ} \mathrm{C}$ & $2 \mathrm{~h}$ & $15: 1$ & $3 w t \%$ & $95 \%$ & [110] \\
\hline $\mathrm{ZrO}_{2}-\mathrm{Al}_{2} \mathrm{O}_{3}$ & Jatropha curcas & $150^{\circ} \mathrm{C}$ & $4 \mathrm{~h}$ & $9: 1$ & $7.61 \mathrm{wt} \%$ & $90.32 \%$ & [111] \\
\hline $\begin{array}{l}\text { KSF clay } \\
\text { Amberlyst }\end{array}$ & Jatropha curcas & $160^{\circ} \mathrm{C}$ & $6 \mathrm{~h}$ & $12: 1$ & $5 w t \%$ & $70 \%$ & [112] \\
\hline $\begin{array}{c}\text { Sulfated } \\
\text { zirconia (SZ) }\end{array}$ & Neem oil & $65^{\circ} \mathrm{C}$ & $2 \mathrm{~h}$ & $9: 1$ & $1 \mathrm{wt} \%$ & $95 \%$ & [101] \\
\hline $\begin{array}{l}\text { Carbon-based } \\
\text { solid acid } \\
\text { catalyst }\end{array}$ & $\begin{array}{l}\text { Waste vegetable } \\
\text { oil }\end{array}$ & $220^{\circ} \mathrm{C}$ & $4.4 \mathrm{~h}$ & $16.8: 1$ & $0.2 w t \%$ & $94.8 \%$ & [102] \\
\hline
\end{tabular}




\subsection{Acid-Base Solid Catalysts}

An acid catalyst is required to esterify low grade oil feedstock to reduce the FFA content prior to transesterification during the production of biodiesel. Thus, catalytic science has given more emphasize to synthesizing a novel heterogeneous catalyst having the desired physical and chemical properties to produce biodiesel from a lower quality of oil feedstock. In this regard, a catalyst having an acid-base character, also known as a bifunctional heterogeneous catalyst, has received great attention for different organic reactions in the last ten years. This type of heterogeneous catalyst has the capability to do both concomitant esterification of FFA and transesterification of the triglycerides available in the oil. As this type of catalyst possesses both active acid and base sites on its surface, it cannot be affected by the present water content or produced water content during biodiesel production. Therefore, biodiesel production costs can be reduced efficiently in this way. Besides, this sort of bifunctional heterogeneous catalyst can simply be modified to insert the required catalyst characteristics for reducing adverse effects due to the presence of FFA and water in low grade feedstock during biodiesel production through the transesterification of triglycerides. Figure 8 depicts the common mechanisms of bifunctional heterogeneous catalysts.

Currently, heterogeneous catalysts that have both basic and acidic sites can concomitantly esterify free fatty acids (FFA) and transesterify triglycerides (TG) to biodiesel production [113]. Rabiah et al. [114] stated on a bifunctional heterogeneous catalyst, bismuth (III) oxide $\left(\mathrm{Bi}_{2} \mathrm{O}_{3}\right)$ supported on a lanthanum oxide $\left(\mathrm{La}_{2} \mathrm{O}_{3}\right)$ catalyst, was prepared by a wet impregnation method with $1-7 \mathrm{wt} \%$ loading of $\mathrm{Bi}_{2} \mathrm{O}_{3}$. The $\mathrm{Bi}_{2} \mathrm{O}_{3}-\mathrm{La}_{2} \mathrm{O}_{3}$ catalyst exhibited a FAME yield of $93 \%$ while maintaining a methanol to oil molar ratio $15: 1$. In addition, they carried out the reaction for $4 \mathrm{~h}$ at $150{ }^{\circ} \mathrm{C}$ with $2 \mathrm{wt} \%$ catalyst. This catalyst possesses good stability with a strong acid-base nature and achieved $87 \%$ conversion after three repeated cycles.

Low grade feedstock like animal fats and waste oils contain FFA and are not suitable for biodiesel production utilizing traditional base facilitated methods due to saponification problems. Bifunctional heterogeneous catalysts possessing both basic and acidic sites were tested to find which could esterify free fatty acids (FFA) and simultaneously transesterify triglycerides (TG) to biodiesel production.

Lin et al. [115] stated the preparation of a mixed metal catalyst of mesoporous calcium silicate with varying amount of calcium oxide. They utilized these catalysts for esterification of free fatty acid (FFA) as well as the transesterification of triglycerides (TG) at the same time. A co-condensation technique was applied during the manufacturing of these catalysts. The mixed metal oxide and tetraethylorthosilicate (TEOS) were reacted in the presence of $\mathrm{NaOH}$ where cetyltrimethyl ammonium bromide (CTAB) supplied the micelles template. After separation, the catalyst was calcined for $6 \mathrm{~h}$ at $600{ }^{\circ} \mathrm{C}$ temperature to make it free from surfactant CTAB. An increased amount of calcium oxide enhanced the structural disorder within the catalyst according to the observation through SEM/TEM. Solid-state NMR revealed that the structure is like crystalline calcium silicate and the total absence of peaks related to $\mathrm{CaO}$ was confirmed by $\mathrm{XRD}$ analysis. Esterification of soybean oil in methanol was done utilizing this catalyst maintaining a $24 \mathrm{~h}$ reaction time at $80^{\circ} \mathrm{C}$ temperature and this catalyst can esterify FFA also. The salvaged catalyst can be used again eight times for esterification as well as thirty times for transesterification with no substantial loss of catalytic performance. 


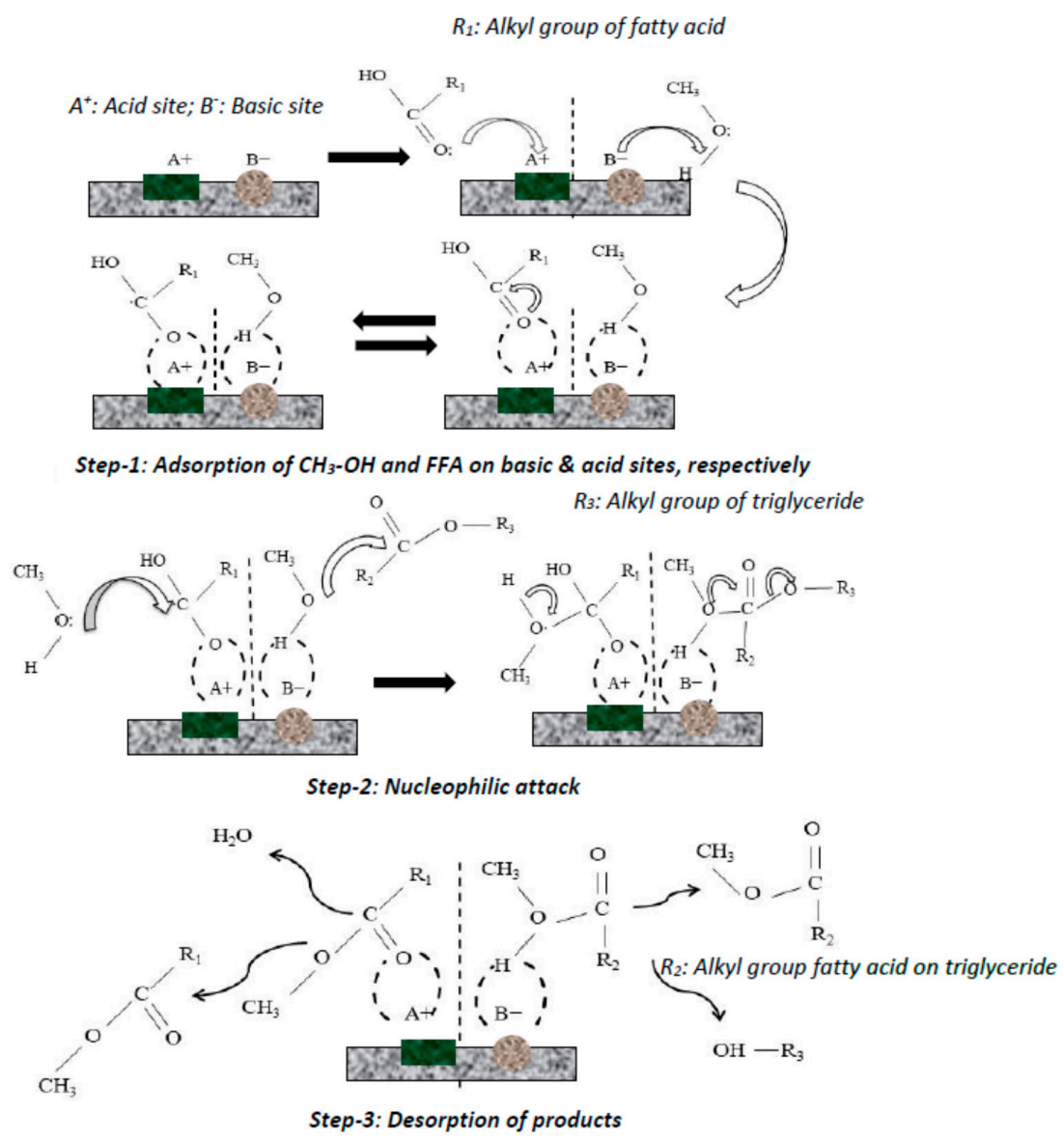

Figure 8. Common mechanism for concomitant esterification and transesterification reactions on a bifunctional heterogeneous catalyst [116].

Moreover, Lin et al. [117] applied a co-condensation technique for the preparation of mesoporous calcium, barium silicate and magnesium silicate and achieved a patent for their work. They prepared a mixed oxide using weak acidic silica and strong basic metal oxide, and in this way, the acidity of silica was increased significantly. In the calcium silicates mixed oxides, Ca sites were basic, silica sites as Lewis acidic and surface containing hydroxyl group acted as the Brönsted acids. The co-condensation method implemented was analogous to the one stated by others mentioned previously [115]. Three different catalysts, containing varying $\mathrm{Ca} / \mathrm{Si}$ ratios, effectively transesterify the soybean oil and found $90-100 \%$ conversion. Complete conversion occurred at $80^{\circ} \mathrm{C}$ temperature, taking $26 \mathrm{~h}$ more. All the catalysts showed promising recyclability and no significant loss was found for twenty repeated uses. Bifunctional heterogeneous catalysts for concomitant esterification and transesterification reactions are summarized in Table 3.

Table 3. Bifunctional heterogeneous catalysts for concurrent esterification and transesterification reactions.

\begin{tabular}{|c|c|c|c|c|c|c|c|c|}
\hline \multirow{2}{*}{ Catalyst } & \multirow{2}{*}{ Feedstock } & \multirow{2}{*}{$\begin{array}{c}\text { FFA } \\
(w t \%)\end{array}$} & \multicolumn{4}{|c|}{ Optimum Reaction Conditions } & \multirow{2}{*}{$\begin{array}{l}\text { Biodiesel } \\
\text { Yield }\end{array}$} & \multirow{2}{*}{ Reference } \\
\hline & & & Temp ${ }^{\circ} \mathrm{C}$ & Time h & Methanol/Oil & $\begin{array}{l}\text { Catalyst } \\
\text { Amount }\end{array}$ & & \\
\hline $\mathrm{Bi}_{2} \mathrm{O}_{3}-\mathrm{La}_{2} \mathrm{O}_{3}$ & Jatropha curcas & 14.5 & 150 & 4 & $15: 1$ & $2 w t \%$ & $93 \%$ & [114] \\
\hline $\mathrm{CaO}-\mathrm{La}_{2} \mathrm{O}_{3}$ & Jatropha curcas & 14.5 & 160 & 3 & $25: 1$ & $3 w t \%$ & $98.76 \%$ & [118] \\
\hline $\mathrm{K} / \mathrm{TiO}_{2}$ & Canola oil & - & 70 & 5 & $36: 1$ & $6 w t \%$ & $100 \%$ & [119] \\
\hline $\mathrm{MgO} / \mathrm{TiO}_{2}$ & Waste cooking oil & 3.6 & 170 & 6 & $50: 1$ & $10 \mathrm{wt} \%$ & $91.6 \%$ & [85] \\
\hline $\begin{array}{l}\mathrm{WO}_{3} / \mathrm{Zr} \\
\mathrm{MCM}-41\end{array}$ & Sunflower oil & 9.1 & 115.5 & 2.5 & 12:1 & $10 \mathrm{wt} \%$ & $79.7 \%$ & [120] \\
\hline $\mathrm{Sr} / \mathrm{ZrO}_{2}$ & $\begin{array}{l}\text { Waste cooking } \\
\text { palm oil }\end{array}$ & 5.08 & 115.4 & 1.2 & 29:1 & $2.7 \mathrm{wt} \%$ & $79.7 \%$ & [116] \\
\hline $\mathrm{MnCeOx}$ & Sunflower oil & 0.07 & 140 & 5 & $12: 1$ & $1 \mathrm{wt} \%$ & $\approx 86 \%$ & [121] \\
\hline
\end{tabular}




\section{Biocatalysts}

Great efforts have been made to examine enzyme catalysts during the transesterification of oils to overcome the saponification problems associated with transesterification of oils having high FFA using a basic catalyst. Enzymatic transesterification can be cost-effective as it acts at a neutral $\mathrm{pH}$ with a lower reaction temperature as well as creating only a small amount of soap. Enzymes can be reused as catalysts by being immobilized on solid supports and supplied with a new frame of opportunity. Different techniques usually were applied for enzymatic immobilization such as cross-linking, covalent bonding, and microencapsulation. Lipases are being utilized as a major enzyme during transesterification because they are cost-effective. Lipases have the capability to catalyze both transesterification of triglycerides(TG) and hydrolysis in moderate conditions and are therefore considered for the production of biodiesel [122-124].

It is recognized that lipases can be used for different synthetic reactions comprising transesterification, aminolysis, and esterification. Some special features of lipases such as enantioselectivity, regioselectivity and specificity permit them to catalyze reactions at a moderate pressure and temperature with the formation of little in the way of by-products. Over the last few decades, special care has been taken for the production of biodiesel using lipases as biocatalysts $[125,126]$.

Sarno et al. (2018) utilized the commercially available lipase from Thermomyces lanuginosus (TL) immobilized on $\mathrm{Fe}_{3} \mathrm{O}_{4} / \mathrm{Au}$ in a solvent free system for the production of biodiesel from spent coffee grounds. After three hours the biodiesel yield was 51.7\%. The 100\% biodiesel yield was achieved within a twenty-four-hour reaction period. The observed reaction kinetics have been considered to be relatively fast. Furthermore, the biocatalyst obtained from the study was applied repeatedly during the transesterification reaction and showed no significant lessening of catalytic activity for three cycles [127]. Saranya et al. (2020) obtained a low-cost biocatalyst by extraction of lipase from Cladosporium tenuissimum CS4 fungal strain. After purification, the obtained biocatalyst was applied for biodiesel production from diatomic microalgal oils. Interestingly, the biocatalysts showed superior performance $(87 \%)$ as compared to the traditional acid catalyst (83\%) [128]. Chen et al. (2017) investigated Pseudomonas mendocina cells immobilized in a magnetically fluidized bed reactor (MFBR) producing biodiesel from biowaste materials [129]. It showed good reusability in MFBR for ten cycles while maintaining the $87.5 \%$ biodiesel yields.

In recent years, nano-biocatalysts have received much attention for the enzymatic production of biodiesel to reduce the massive cost of lipase $[130,131]$. In this regard, nanomaterials have been broadly utilized for enzyme immobilization [132]. Nanomaterials are predominantly effective means for the advancement of immobilized enzymes due to their large surface area, particle size, and high enzyme loading capacity [133]. Miao et al. (2018) prepared the surface amino-functionalized magnetic nanoparticles (APTES- $\mathrm{Fe}_{3} \mathrm{O}_{4}$ ) as a immobilization material of lipase and used the glutaraldehyde as a coupling agent for making a covalent bond between lipase APTES- $\mathrm{Fe}_{3} \mathrm{O}_{4}$ magnetic nanoparticles. They obtained $89.4 \%$ biodiesel yield during the transesterification reaction under optimum conditions [134]. Nematian et al. (2020) applied the modified nano-biocatalyst for the production of biodiesel from Chlorella vulgaris microalgae oil with $35 \%$ lipid content. They developed the improved nano-biocatalyst by loading Rhizopus oryzae lipase (ROL) on $\mathrm{Fe}_{3} \mathrm{O}_{4}$ superparamagnetic nanoparticles (MNPs) with covalent bonding and electrostatic attractions. They reported about $75 \%$ fatty acid methyl ester (FAME) conversion using their modified catalyst during the nanocatalyzed transesterification process [135]. Narayanan and Pandey (2018) utilized the nanosilicon immobilized lipase for the production of biodiesel in an improved reverse fluidized bed bioreactor. They mentioned that a more than $80 \%$ conversion rate can be achieved in the bioreactor under optimized conditions [136].

\section{Summary of the Effect of a Heterogeneous Catalyst on the Yield of Biodiesel}

Based on review, several investigations were carried out on heterogeneous catalysts with the goal of obtaining solutions to the challenges related to the use of homogeneous catalysts to produce biodiesel. Consequently, a significant number of heterogeneous catalysts have been evaluated and many of them 
have shown good catalytic activity. The different heterogeneous catalysts for the transesterification of various feedstocks, along with microalgal oil are summarized in Table 4.

Obviously, microalgae have received great interest as an area of current research for biodiesel production because they have the capability to provide enough fuel for global expenditure [137]. Additionally, due to their high lipid contents and faster growth rate, microalgae could decrease the contest with respect to the use of land for other traditional crops and can reduce the disputes over food-for-fuel. They have the potential to lower the impact of greenhouse gases through $\mathrm{CO}_{2}$ biofixation. On the other hand, microalgal oil contains high free fatty acids (FFAs) which demand prior treatment if traditional homogeneous catalysts are utilized. A critical survey (Table 4) of the literature proposes that higher biodiesel yields (90-99.5\%) can be achieved from microalgal oil applying heterogeneous catalysts. Due to the formation of soap and post-production processes, heterogeneous base catalysts are not well-suited for biodiesel production, thus, the requirement for using solid acid catalysts. However, the solid acid catalyst needs elevated reaction temperatures and prolonged time to attain the highest conversion rate for some cases [99]. In this regard, the bifunctional heterogeneous catalyst with an acid-base character has acquired more attention for different organic reactions at this time [113]. 
Table 4. Various heterogeneous catalysts for transesterification reaction: optimum parameter condition, feedstock, and biodiesel yield.

\begin{tabular}{|c|c|c|c|c|}
\hline Feedstock & Catalyst & Optimum Reaction Conditions & Yield (wt\%) & Reference \\
\hline Sunflower oil & Fe-Zn double metal cyanide (DMC) & $\mathrm{MeOH} / \mathrm{Oil}=15: 1$, Cat. $=3 \mathrm{wt} \%, \mathrm{t}=8 \mathrm{~h}, \mathrm{~T}=170^{\circ} \mathrm{C}$ & 92 & [63] \\
\hline Sunflower oil & $\mathrm{ZrO}_{2}$ supported $\mathrm{La}_{2} \mathrm{O}_{3}$ catalyst & $\mathrm{MeOH} / \mathrm{Oil}=3: 1$, Cat. $=2 \mathrm{wt} \%, \mathrm{t}=5 \mathrm{~h}, \mathrm{~T}=60^{\circ} \mathrm{C}$ & 84.9 & [138] \\
\hline Soybean oil & $\mathrm{ZnO}$ loaded with $\mathrm{Sr}\left(\mathrm{NO}_{3}\right)_{2}$ & $\mathrm{MeOH} / \mathrm{Oil}=12: 1$, Cat. $=5 \mathrm{wt} \%, \mathrm{t}=4 \mathrm{~h}, \mathrm{~T}=65^{\circ} \mathrm{C}$ & 94.7 & [139] \\
\hline Soybean oil & $\mathrm{S}-\mathrm{ZrO}_{2}$ & $\mathrm{MeOH} / \mathrm{Oil}=20: 1$, Cat. $=5 \mathrm{wt} \%, \mathrm{t}=1 \mathrm{~h}, \mathrm{~T}=120^{\circ} \mathrm{C}$ & 98.6 & [140] \\
\hline Palm oil & $\mathrm{CaO}$ from eggshells & $\mathrm{MeOH} / \mathrm{Oil}=18: 1$, Cat. $=10 \mathrm{wt} \%, \mathrm{t}=2 \mathrm{~h}, \mathrm{~T}=65^{\circ} \mathrm{C}$ & 98 & {$[81]$} \\
\hline Palm oil & $\mathrm{CaO} / \mathrm{Al}_{2} \mathrm{O}_{3}$ & $\mathrm{MeOH} / \mathrm{Oil}=12: 1$, Cat. $=1.3 \mathrm{wt} \%, \mathrm{t}=5 \mathrm{~h}, \mathrm{~T}=64.29^{\circ} \mathrm{C}$ & 98.64 & {$[76]$} \\
\hline Palm oil & $\mathrm{KF} / \mathrm{Ca}-\mathrm{Al}$ hydrotalcite & $\mathrm{MeOH} / \mathrm{Oil}=12: 1$, Cat. $=4 \mathrm{wt} \%, \mathrm{t}=5 \mathrm{~h}, \mathrm{~T}=65^{\circ} \mathrm{C}$ & 97.98 & [90] \\
\hline Rapeseed oil & $\mathrm{KNO}_{3} / \mathrm{CaO}$ & $\mathrm{MeOH} / \mathrm{Oil}=6: 1$, Cat. $=1 \mathrm{wt} \%, \mathrm{t}=3 \mathrm{~h}, \mathrm{~T}=65^{\circ} \mathrm{C}$ & 98 & [83] \\
\hline Waste cooking oil & $\mathrm{MgO} / \mathrm{TiO}_{2}$ & $\mathrm{MeOH} / \mathrm{Oil}=50: 1$, Cat. $=10 \mathrm{wt} \%, \mathrm{t}=6 \mathrm{~h}, \mathrm{~T}=170^{\circ} \mathrm{C}$ & 91.6 & {$[77]$} \\
\hline Jatropha oil & $\mathrm{Mg}-\mathrm{Al}$ hydrotalcite & $\mathrm{MeOH} / \mathrm{Oil}=4: 1$, Cat. $=1 \mathrm{wt} \%, \mathrm{t}=1.5 \mathrm{~h}, \mathrm{~T}=45^{\circ} \mathrm{C}$ & 95.2 & [141] \\
\hline Soybean oil & Sodium silicate & $\mathrm{MeOH} / \mathrm{Oil}=7 \cdot 5: 1$, Cat. $=3 \mathrm{wt} \%, \mathrm{t}=1 \mathrm{~h}, \mathrm{~T}=60^{\circ} \mathrm{C}$ & 100 & [94] \\
\hline Moringa oleifera oil & $\mathrm{SO}_{4}{ }^{2-} / \mathrm{SnO}_{2}-\mathrm{SiO}_{2}$ & $\mathrm{MeOH} / \mathrm{Oil}=19.5: 1$, Cat. $=3 \mathrm{wt} \%, \mathrm{t}=2.5 \mathrm{~h}, \mathrm{~T}=150^{\circ} \mathrm{C}$ & 84 & [109] \\
\hline Purified palm oil & $\mathrm{SO}_{4}-\mathrm{ZrO}_{2}$ & $\mathrm{MeOH} / \mathrm{Oil}=25: 1$, Cat. $=0.5 \mathrm{wt} \%, \mathrm{t}=10 \mathrm{~min}, \mathrm{~T}=250^{\circ} \mathrm{C}$ & 90 & [142] \\
\hline Sunflower oil & $\mathrm{SO}_{4}{ }^{2-} / \mathrm{ZrO}_{2} / \mathrm{SiO}_{2}$ & Ethanol $/$ Oil $=12: 1$, Cat. $=4.6 \mathrm{wt} \%, \mathrm{t}=6 \mathrm{~h}, \mathrm{~T}=200^{\circ} \mathrm{C}$ & 91.5 & [120] \\
\hline Cottonseed oil & Carbon based solid acid & $\mathrm{MeOH} / \mathrm{Oil}=16.8: 1$, Cat. $=0.2 \mathrm{wt} \%, \mathrm{t}=4.5 \mathrm{~h}, \mathrm{~T}=220^{\circ} \mathrm{C}$ & 94.8 & [102] \\
\hline Croton megalocarpus oil & $\mathrm{SO}_{4}{ }^{2-} / \mathrm{SnO}_{2}-\mathrm{SiO}_{2}$ & $\mathrm{MeOH} / \mathrm{Oil}=15: 1$, Cat. $=3 \mathrm{wt} \%, \mathrm{t}=2 \mathrm{~h}, \mathrm{~T}=180^{\circ} \mathrm{C}$ & 95 & [110] \\
\hline Algae oil & Zirconia, titania & Not reported & 90.20 & [143] \\
\hline Algae oil & $4 \% \mathrm{NiO}, 18 \% \mathrm{MoO}_{3} /$ alumina & $\mathrm{T}=370^{\circ} \mathrm{C}$ & 99.00 & [144] \\
\hline Algae oil & Amberlyst-15 & Not reported & 98 & [145] \\
\hline Algae oil & Hierarchical H-Beta zeolites & Not reported & 99.5 & [144] \\
\hline Algae oil & Microporous titania & Not reported & 94.7 & [144] \\
\hline Microalgal's lipid & Modified Alumina & Not reported & 97.5 & {$[75]$} \\
\hline Freshwater microalgae oil & Modified titania & Not reported & 95 & [64] \\
\hline
\end{tabular}




\section{Conclusions}

Biodiesel is a sustainable, renewable, and environmentally benign alternative fuel for diesel engines. Transesterification of vegetable oil and animal fats or algal oil in the presence of methanol using a suitable catalyst are good practices for the production of biodiesel. Microalgal lipid is mostly triacylglyceride that can be transformed into biodiesel as fatty acid methyl esters via transesterification. Transesterification reactions face some challenges connected to the existence of free fatty acid (FFA) in the feedstock and the biphasic (immiscible) character of the reactants like methanol oil. The advancement of efficient and economical catalysts with an environmentally benign process are essential to overcome the problems associated with biodiesel production from microalgal oil. Recently, despite a few difficulties, heterogeneous catalysts have shown a promising nature over homogeneous catalysts for biodiesel production from third generation feedstock like microalgae. More effective catalytic practices need improvement in terms of catalyst activity and selectivity. Enzymatic catalysts, though highly promising, have a rather slow rate of biological reactions. In this context, the occurrence of basic and acidic sites on the surface of heterogeneous acid-base catalysts could be the best option for future developments in order to produce biodiesel from algal oil. Acid-base catalysts are one of the potential catalysts due to their ability to catalyze both free fatty acids (FFAs) in esterification reactions and triglycerides (TG) in transesterification reactions at the same time. For an effective commercial catalyst, recyclability, lower costs, and catalyst lifetime are highly essential as these have a straightforward impact on the total cost of the process related with biodiesel production.

Author Contributions: Writing of the review manuscript draft, M.O.F.; Review and writing of manuscript, M.M.H. and S.A.R. Project administration and funding acquisition, M.M.H. All authors have read and agreed to the published version of the manuscript.

Funding: This research was funded by the Deanship of Scientific Research (DSR) at King Fahd University of Petroleum \& Minerals (KFUPM) through project No. IN161022.

Acknowledgments: The authors would like to acknowledge the support provided by the Deanship of Scientific Research (DSR) at King Fahd University of Petroleum \& Minerals (KFUPM) for funding this work through project no. IN161022.

Conflicts of Interest: The authors declare no conflict of interest.

\section{References}

1. Wong, W.Y.; Lim, S.; Pang, Y.L.; Shuit, S.H.; Chen, W.H.; Lee, K.T. Synthesis of renewable heterogeneous acid catalyst from oil palm empty fruit bunch for glycerol-free biodiesel production. Sci. Total Environ. 2020. [CrossRef]

2. Sharma, S.; Saxena, V.; Baranwal, A.; Chandra, P.; Pandey, L.M. Engineered nanoporous materials mediated heterogeneous catalysts and their implications in biodiesel production. Mater. Sci. Energy Technol. 2018. [CrossRef]

3. De Bhowmick, G.; Subramanian, G.; Mishra, S.; Sen, R. Raceway pond cultivation of a marine microalga of Indian origin for biomass and lipid production: A case study. Algal Res. 2014, 6, 201-209. [CrossRef]

4. Wilbanks, T.J.; Fernandez, S. Climate Change and Infrastructure, Urban Systems, and Vulnerabilities: Technical Report for the US Department of Energy in Support of the National Climate Assessment; National Climate Assessment Regional Technical Input Report Series; Island Press: Washington, DC, USA, 2014.

5. Nayak, M.; Karemore, A.; Sen, R. Performance evaluation of microalgae for concomitant wastewater bioremediation, $\mathrm{CO}_{2}$ biofixation and lipid biosynthesis for biodiesel application. Algal Res. 2016, 16, 216-223. [CrossRef]

6. Panwar, N.L.; Kaushik, S.C.; Kothari, S. Role of renewable energy sources in environmental protection: A review. Renew. Sustain. Energy Rev. 2011, 15, 1513-1524. [CrossRef]

7. Ahmadi, M.H.; Ghazvini, M.; Nazari, M.A.; Ahmadi, M.A.; Pourfayaz, F.; Lorenzini, G.; Ming, T. Renewable energy harvesting with the application of nanotechnology: A review. Int. J. Energy Res. 2019, 43, 1387-1410. [CrossRef] 
8. Bouraiou, A.; Necaibia, A.; Boutasseta, N.; Mekhilef, S.; Dabou, R.; Ziane, A.; Sahouane, N.; Attoui, I.; Mostefaoui, M.; Touaba, O. Status of renewable energy potential and utilization in Algeria. J. Clean. Prod. 2020. [CrossRef]

9. Furlan, C.; Mortarino, C. Forecasting the impact of renewable energies in competition with non-renewable sources. Renew. Sustain. Energy Rev. 2018, 81, 1879-1886. [CrossRef]

10. Singh, R.; Bux, F.; Sharma, Y.C. Optimization of biodiesel synthesis from microalgal (Spirulina platensis) oil by using a novel heterogeneous catalyst, $\beta$-strontium silicate $\left(\beta-\mathrm{Sr}_{2} \mathrm{SiO}_{4}\right)$. Fuel 2020. [CrossRef]

11. Mohtasham, J. Review article-renewable energies. Energy Procedia 2015, 74, 1289-1297. [CrossRef]

12. Azarpour, A.; Suhaimi, S.; Zahedi, G.; Bahadori, A. A review on the drawbacks of renewable energy as a promising energy source of the future. Arab. J. Sci. Eng. 2013. [CrossRef]

13. Manzanera, M.; Molina-Munoz, M.; Gonzalez-Lopez, J. Biodiesel: An alternative fuel. Recent Pat. Biotechnol. 2008. [CrossRef] [PubMed]

14. Asri, N.P.; Machmudah, S.; Wahyudiono, S.; Budikarjono, K.; Roesyadi, A.; Goto, M. Palm oil transesterification in sub- and supercritical methanol with heterogeneous base catalyst. Chem. Eng. Process. Process Intensif. 2013. [CrossRef]

15. Uddin, M.R.; Ferdous, K.; Uddin, M.R.; Khan, M.R.; Islam, M.A. Synthesis of biodiesel from waste cooking oil. Chem. Eng. Sci. 2013. [CrossRef]

16. Aransiola, E.F.; Ojumu, T.V.; Oyekola, O.O.; Madzimbamuto, T.F.; Ikhu-Omoregbe, D.I.O. A review of current technology for biodiesel production: State of the art. Biomass Bioenergy 2014, 61, 276-297. [CrossRef]

17. Helwani, Z.; Othman, M.R.; Aziz, N.; Fernando, W.J.N.; Kim, J. Technologies for production of biodiesel focusing on green catalytic techniques: A review. Fuel Process. Technol. 2009. [CrossRef]

18. Feng, Y.; He, B.; Cao, Y.; Li, J.; Liu, M.; Yan, F.; Liang, X. Biodiesel production using cation-exchange resin as heterogeneous catalyst. Bioresour. Technol. 2010. [CrossRef]

19. Nahar, G.; Kendall, K. Biodiesel formulations as fuel for internally reforming solid oxide fuel cell. Fuel Process. Technol. 2011. [CrossRef]

20. Dhawane, S.H.; Kumar, T.; Halder, G. Recent advancement and prospective of heterogeneous carbonaceous catalysts in chemical and enzymatic transformation of biodiesel. Energy Convers. Manag. 2018, 167, 176-202. [CrossRef]

21. Sharma, Y.C.; Singh, B.; Upadhyay, S.N. Advancements in development and characterization of biodiesel: A review. Fuel 2008, 87, 2355-2373. [CrossRef]

22. Rizwanul Fattah, I.M.; Ong, H.C.; Mahlia, T.M.I.; Mofijur, M.; Silitonga, A.S.; Rahman, S.M.A.; Ahmad, A. State of the art of catalysts for biodiesel production. Front. Energy Res. 2020, 8, 101. [CrossRef]

23. Sianipar, R.N.R.; Ariyani, D.; Nata, I.F. Conversion of palm oil sludge to biodiesel using alum and $\mathrm{KOH}$ as catalysts. Sustain. Environ. Res. 2017. [CrossRef]

24. Chamola, R.; Khan, M.F.; Raj, A.; Verma, M.; Jain, S. Response surface methodology based optimization of in situ transesterification of dry algae with methanol, $\mathrm{H}_{2} \mathrm{SO}_{4}$ and $\mathrm{NaOH}$. Fuel 2019. [CrossRef]

25. Shi, W.; Li, J.; He, B.; Yan, F.; Cui, Z.; Wu, K.; Lin, L.; Qian, X.; Cheng, Y. Biodiesel production from waste chicken fat with low free fatty acids by an integrated catalytic process of composite membrane and sodium methoxide. Bioresour. Technol. 2013. [CrossRef] [PubMed]

26. Celante, D.; Schenkel, J.V.D.; de Castilhos, F. Biodiesel production from soybean oil and dimethyl carbonate catalyzed by potassium methoxide. Fuel 2018. [CrossRef]

27. Fukuda, H.; Kondo, A.; Noda, H. Biodiesel fuel production by transesterification of oils. J. Biosci. Bioeng. 2001, 92, 405-416. [CrossRef]

28. Granados, M.L.; Poves, M.D.Z.; Alonso, D.M.; Mariscal, R.; Galisteo, F.C.; Moreno-Tost, R.; Santamaría, J.; Fierro, J.L.G. Biodiesel from sunflower oil by using activated calcium oxide. Appl. Catal. B Environ. 2007. [CrossRef]

29. Ji, J.; Wang, J.; Li, Y.; Yu, Y.; Xu, Z. Preparation of biodiesel with the help of ultrasonic and hydrodynamic cavitation. Ultrasonics 2006. [CrossRef]

30. Karmee, S.K.; Chadha, A. Preparation of biodiesel from crude oil of Pongamia pinnata. Bioresour. Technol. 2005. [CrossRef]

31. Lee, J.S.; Saka, S. Biodiesel production by heterogeneous catalysts and supercritical technologies. Bioresour. Technol. 2010, 101, 7191-7200. [CrossRef] 
32. Dossin, T.F.; Reyniers, M.F.; Berger, R.J.; Marin, G.B. Simulation of heterogeneously MgO-catalyzed transesterification for fine-chemical and biodiesel industrial production. Appl. Catal. B Environ. 2006. [CrossRef]

33. Mbaraka, I.K.; Shanks, B.H. Conversion of oils and fats using advanced mesoporous heterogeneous catalysts. JAOCS J. Am. Oil Chem. Soc. 2006, 83, 79-91. [CrossRef]

34. Colombo, K.; Ender, L.; Barros, A.A.C. The study of biodiesel production using $\mathrm{CaO}$ as a heterogeneous catalytic reaction. Egypt. J. Pet. 2017, 26, 341-349. [CrossRef]

35. Wang, L.; Yang, J. Transesterification of soybean oil with nano-MgO or not in supercritical and subcritical methanol. Fuel 2007. [CrossRef]

36. Endalew, A.K.; Kiros, Y.; Zanzi, R. Heterogeneous catalysis for biodiesel production from Jatropha curcas oil (JCO). Energy 2011, 36, 2693-2700. [CrossRef]

37. Kansedo, J.; Lee, K.T.; Bhatia, S. Cerbera odollam (sea mango) oil as a promising non-edible feedstock for biodiesel production. Fuel 2009. [CrossRef]

38. Viriya-Empikul, N.; Krasae, P.; Nualpaeng, W.; Yoosuk, B.; Faungnawakij, K. Biodiesel production over Ca-based solid catalysts derived from industrial wastes. Fuel 2012. [CrossRef]

39. Razzak, S.A.; Hossain, M.M.; Lucky, R.A.; Bassi, A.S.; De Lasa, H. Integrated $\mathrm{CO}_{2}$ capture, wastewater treatment and biofuel production by microalgae culturing-A review. Renew. Sustain. Energy Rev. 2013, 27, 622-653. [CrossRef]

40. Zhang, X.; Rong, J.; Chen, H.; He, C.; Wang, Q. Current status and outlook in the application of microalgae in biodiesel production and environmental protection. Front. Energy Res. 2014, 2, 32. [CrossRef]

41. Mata, T.M.; Martins, A.A.; Caetano, N.S. Microalgae for biodiesel production and other applications: A review. Renew. Sustain. Energy Rev. 2010, 14, 217-232. [CrossRef]

42. Rittmann, B.E. Opportunities for renewable bioenergy using microorganisms. Biotechnol. Bioeng. 2008, 100, 203-212. [CrossRef]

43. Meher, L.C.; Vidya Sagar, D.; Naik, S.N. Technical aspects of biodiesel production by transesterification-A review. Renew. Sustain. Energy Rev. 2006, 10, 248-268. [CrossRef]

44. Schenk, P.M.; Thomas-Hall, S.R.; Stephens, E.; Marx, U.C.; Mussgnug, J.H.; Posten, C.; Kruse, O.; Hankamer, B. Second generation biofuels: High-efficiency microalgae for biodiesel production. BioEnergy Res. 2008. [CrossRef]

45. Chisti, Y. Biodiesel from microalgae. Biotechnol. Adv. 2007, 25, 294-306. [CrossRef]

46. Demirbas, M.F. Biofuels from algae for sustainable development. Appl. Energy 2011. [CrossRef]

47. Hidalgo, P.; Toro, C.; Ciudad, G.; Schober, S.; Mittelbach, M.; Navia, R. Evaluation of different operational strategies for biodiesel production by direct transesterification of microalgal biomass. Energy Fuels 2014, 28, 3814-3820. [CrossRef]

48. Williams, P.J.L.B.; Laurens, L.M.L. Microalgae as biodiesel \& biomass feedstocks: Review \& analysis of the biochemistry, energetics \& economics. Energy Environ. Sci. 2010, 3, 554-590.

49. Kim, J.; Yoo, G.; Lee, H.; Lim, J.; Kim, K.; Kim, C.W.; Park, M.S.; Yang, J.W. Methods of downstream processing for the production of biodiesel from microalgae. Biotechnol. Adv. 2013, 31, 862-876. [CrossRef]

50. Galadima, A.; Muraza, O. Biodiesel production from algae by using heterogeneous catalysts: A critical review. Energy 2014, 78, 72-83. [CrossRef]

51. Babu, B.V. Biomass pyrolysis: A state-of-the-art review. Biofuels Bioprod. Biorefin. 2008, 2, 393-414. [CrossRef]

52. Bahadur, N.P.; Boocock, D.G.B.; Konar, S.K. Liquid hydrocarbons from catalytic pyrolysis of sewage sludge lipid and canola oil: Evaluation of fuel properties. Energy Fuels 1995. [CrossRef]

53. Boateng, A.A.; Mullen, C.A.; Goldberg, N.; Hicks, K.B.; Jung, H.J.G.; Lamb, J.F.S. Production of bio-oil from alfalfa stems by fluidized-bed fast pyrolysis. Ind. Eng. Chem. Res. 2008. [CrossRef]

54. Nautiyal, P.; Subramanian, K.A.; Dastidar, M.G. Production and characterization of biodiesel from algae. Fuel Process. Technol. 2014. [CrossRef]

55. Ma, F.; Hanna, M.A. Biodiesel production: A review. Bioresour. Technol. 1999, 70, 1-15. [CrossRef]

56. Haas, M. The interplay between feedstock quality and esterification technology in biodiesel production. Lipid Technol. 2004, 16, 7-11.

57. Diasakou, M.; Louloudi, A.; Papayannakos, N. Kinetics of the non-catalytic transesterification of soybean oil. Fuel 1998. [CrossRef] 
58. Kusdiana, D.; Saka, S. Kinetics of transesterification in rapeseed oil to biodiesel fuel as treated in supercritical methanol. Fuel 2001. [CrossRef]

59. Borges, M.E.; Díaz, L. Recent developments on heterogeneous catalysts for biodiesel production by oil esterification and transesterification reactions: A review. Renew. Sustain. Energy Rev. 2012, 16, 2839-2849. [CrossRef]

60. Guldhe, A.; Moura, C.V.R.; Singh, P.; Rawat, I.; Moura, E.M.; Sharma, Y.; Bux, F. Conversion of microalgal lipids to biodiesel using chromium-aluminum mixed oxide as a heterogeneous solid acid catalyst. Renew. Energy 2017. [CrossRef]

61. Leung, D.Y.C.; Wu, X.; Leung, M.K.H. A review on biodiesel production using catalyzed transesterification. Appl. Energy 2010, 87, 1083-1095. [CrossRef]

62. Ono, Y.; Baba, T. Selective reactions over solid base catalysts. Catal. Today 1997, 38, 321-337. [CrossRef]

63. Yoo, S.J.; Lee, H.S.; Veriansyah, B.; Kim, J.; Kim, J.D.; Lee, Y.W. Synthesis of biodiesel from rapeseed oil using supercritical methanol with metal oxide catalysts. Bioresour. Technol. 2010. [CrossRef] [PubMed]

64. Chouhan, A.P.S.; Sarma, A.K. Modern heterogeneous catalysts for biodiesel production: A comprehensive review. Renew. Sustain. Energy Rev. 2011, 15, 4378-4399. [CrossRef]

65. López, D.E.; Goodwin, J.G.; Bruce, D.A.; Lotero, E. Transesterification of triacetin with methanol on solid acid and base catalysts. Appl. Catal. A Gen. 2005. [CrossRef]

66. Di Serio, M.; Tesser, R.; Dimiccoli, M.; Cammarota, F.; Nastasi, M.; Santacesaria, E. Synthesis of biodiesel via homogeneous Lewis acid catalyst. J. Mol. Catal. A Chem. 2005. [CrossRef]

67. Liu, X.; He, H.; Wang, Y.; Zhu, S.; Piao, X. Transesterification of soybean oil to biodiesel using CaO as a solid base catalyst. Fuel 2008. [CrossRef]

68. Kouzu, M.; Hidaka, J.S. Transesterification of vegetable oil into biodiesel catalyzed by CaO: A review. Fuel 2012, 93, 1-12. [CrossRef]

69. Veljković, V.B.; Stamenković, O.S.; Todorović, Z.B.; Lazić, M.L.; Skala, D.U. Kinetics of sunflower oil methanolysis catalyzed by calcium oxide. Fuel 2009. [CrossRef]

70. Viola, E.; Blasi, A.; Valerio, V.; Guidi, I.; Zimbardi, F.; Braccio, G.; Giordano, G. Biodiesel from fried vegetable oils via transesterification by heterogeneous catalysis. Catal. Today 2012, 179, 185-190. [CrossRef]

71. Zhu, H.; Wu, Z.; Chen, Y.; Zhang, P.; Duan, S.; Liu, X.; Mao, Z. Preparation of biodiesel catalyzed by solid super base of calcium oxide and its refining process. Chin. J. Catal. 2006. [CrossRef]

72. Kawashima, A.; Matsubara, K.; Honda, K. Acceleration of catalytic activity of calcium oxide for biodiesel production. Bioresour. Technol. 2009. [CrossRef] [PubMed]

73. Puna, J.F.; Gomes, J.F.; Correia, M.J.N.; Soares Dias, A.P.; Bordado, J.C. Advances on the development of novel heterogeneous catalysts for transesterification of triglycerides in biodiesel. Fuel 2010. [CrossRef]

74. Liu, X.; He, H.; Wang, Y.; Zhu, S. Transesterification of soybean oil to biodiesel using SrO as a solid base catalyst. Catal. Commun. 2007. [CrossRef]

75. Umdu, E.S.; Tuncer, M.; Seker, E. Transesterification of Nannochloropsis oculata microalga's lipid to biodiesel on $\mathrm{Al}_{2} \mathrm{O}_{3}$ supported $\mathrm{CaO}$ and $\mathrm{MgO}$ catalysts. Bioresour. Technol. 2009, 100, 2828-2831. [CrossRef]

76. Zabeti, M.; Daud, W.M.A.W.; Aroua, M.K. Biodiesel production using alumina-supported calcium oxide: An optimization study. Fuel Process. Technol. 2010. [CrossRef]

77. Wen, Z.; Yu, X.; Tu, S.T.; Yan, J.; Dahlquist, E. Biodiesel production from waste cooking oil catalyzed by $\mathrm{TiO}_{2}-\mathrm{MgO}$ mixed oxides. Bioresour. Technol. 2010. [CrossRef]

78. Li, Y.; Lian, S.; Tong, D.; Song, R.; Yang, W.; Fan, Y.; Qing, R.; Hu, C. One-step production of biodiesel from Nannochloropsis sp. on solid base Mg-Zr catalyst. Appl. Energy 2011. [CrossRef]

79. Lee, A.F.; Bennett, J.A.; Manayil, J.C.; Wilson, K. Heterogeneous catalysis for sustainable biodiesel production via esterification and transesterification. Chem. Soc. Rev. 2014, 43, 7887-7916. [CrossRef]

80. Deka, D.C.; Basumatary, S. High quality biodiesel from yellow oleander (Thevetia peruviana) seed oil. Biomass Bioenergy 2011. [CrossRef]

81. Cho, Y.B.; Seo, G. High activity of acid-treated quail eggshell catalysts in the transesterification of palm oil with methanol. Bioresour. Technol. 2010. [CrossRef]

82. Verziu, M.; Coman, S.M.; Richards, R.; Parvulescu, V.I. Transesterification of vegetable oils over CaO catalysts. Catal. Today 2011, 167, 64-70. [CrossRef]

83. Encinar, J.M.; González, J.F.; Pardal, A.; Martínez, G. Rape oil transesterification over heterogeneous catalysts. Fuel Process. Technol. 2010. [CrossRef] 
84. Liu, C.; Lv, P.; Yuan, Z.; Yan, F.; Luo, W. The nanometer magnetic solid base catalyst for production of biodiesel. Renew. Energy 2010. [CrossRef]

85. Wen, Z.; Yu, X.; Tu, S.T.; Yan, J.; Dahlquist, E. Synthesis of biodiesel from vegetable oil with methanol catalyzed by Li-doped magnesium oxide catalysts. Appl. Energy 2010. [CrossRef]

86. Mutreja, V.; Singh, S.; Ali, A. Biodiesel from mutton fat using $\mathrm{KOH}$ impregnated $\mathrm{MgO}$ as heterogeneous catalysts. Renew. Energy 2011. [CrossRef]

87. Ngamcharussrivichai, C.; Nunthasanti, P.; Tanachai, S.; Bunyakiat, K. Biodiesel production through transesterification over natural calciums. Fuel Process. Technol. 2010. [CrossRef]

88. Ilgen, O. Dolomite as a heterogeneous catalyst for transesterification of canola oil. Fuel Process. Technol. 2011. [CrossRef]

89. Taufiq-Yap, Y.H.; Lee, H.V.; Hussein, M.Z.; Yunus, R. Calcium-based mixed oxide catalysts for methanolysis of Jatropha curcas oil to biodiesel. Biomass Bioenergy 2011. [CrossRef]

90. Gao, L.; Teng, G.; Xiao, G.; Wei, R. Biodiesel from palm oil via loading KF/Ca-Al hydrotalcite catalyst. Biomass Bioenergy 2010, 34, 1283-1288. [CrossRef]

91. Silva, C.C.C.M.; Ribeiro, N.F.P.; Souza, M.M.V.M.; Aranda, D.A.G. Biodiesel production from soybean oil and methanol using hydrotalcites as catalyst. Fuel Process. Technol. 2010. [CrossRef]

92. Deng, X.; Fang, Z.; Liu, Y.H.; Yu, C.L. Production of biodiesel from Jatropha oil catalyzed by nanosized solid basic catalyst. Energy 2011. [CrossRef]

93. Samart, C.; Chaiya, C.; Reubroycharoen, P. Biodiesel production by methanolysis of soybean oil using calcium supported on mesoporous silica catalyst. Energy Convers. Manag. 2010. [CrossRef]

94. Guo, F.; Peng, Z.G.; Dai, J.Y.; Xiu, Z.L. Calcined sodium silicate as solid base catalyst for biodiesel production. Fuel Process. Technol. 2010. [CrossRef]

95. Boro, J.; Thakur, A.J.; Deka, D. Solid oxide derived from waste shells of Turbonilla striatula as a renewable catalyst for biodiesel production. Fuel Process. Technol. 2011. [CrossRef]

96. Wei, Z.; Xu, C.; Li, B. Application of waste eggshell as low-cost solid catalyst for biodiesel production. Bioresour. Technol. 2009. [CrossRef]

97. Lotero, E.; Liu, Y.; Lopez, D.E.; Suwannakarn, K.; Bruce, D.A.; Goodwin, J.G. Synthesis of biodiesel via acid catalysis. Ind. Eng. Chem. Res. 2005. [CrossRef]

98. Meher, L.C.; Churamani, C.P.; Arif, M.; Ahmed, Z.; Naik, S.N. Jatropha curcas as a renewable source for bio-fuels-A review. Renew. Sustain. Energy Rev. 2013, 26, 397-407. [CrossRef]

99. Furuta, S.; Matsuhashi, H.; Arata, K. Biodiesel fuel production with solid superacid catalysis in fixed bed reactor under atmospheric pressure. Catal. Commun. 2004. [CrossRef]

100. Helwani, Z.; Othman, M.R.; Aziz, N.; Kim, J.; Fernando, W.J.N. Solid heterogeneous catalysts for transesterification of triglycerides with methanol: A review. Appl. Catal. A Gen. 2009, 363, 1-10. [CrossRef]

101. Muthu, H.; Selvabala, V.S.; Varathachary, T.K.; Selvaraj, D.K.; Nandagopal, J.; Subramanian, S. Synthesis of biodiesel from neem oil using sulfated zirconia via tranesterification. Braz. J. Chem. Eng. 2010. [CrossRef]

102. Shu, Q.; Gao, J.; Nawaz, Z.; Liao, Y.; Wang, D.; Wang, J. Synthesis of biodiesel from waste vegetable oil with large amounts of free fatty acids using a carbon-based solid acid catalyst. Appl. Energy 2010, 87, 2589-2596. [CrossRef]

103. Brucato, A.; Busciglio, A.; Di Stefano, F.; Grisafi, F.; Micale, G.; Scargiali, F. High temperature solid-catalized transesterification for biodiesel production. Chem. Eng. Trans. 2010, 19, 31-36.

104. Yan, S.; Dimaggio, C.; Mohan, S.; Kim, M.; Salley, S.O.; Ng, K.Y.S. Advancements in heterogeneous catalysis for biodiesel synthesis. Top. Catal. 2010. [CrossRef]

105. Kiss, A.A.; Dimian, A.C.; Rothenberg, G. Solid acid catalysts for biodiesel production-Towards sustainable energy. Adv. Synth. Catal. 2006. [CrossRef]

106. Park, Y.M.; Lee, D.W.; Kim, D.K.; Lee, J.S.; Lee, K.Y. The heterogeneous catalyst system for the continuous conversion of free fatty acids in used vegetable oils for the production of biodiesel. Catal. Today 2008. [CrossRef]

107. Peng, B.X.; Shu, Q.; Wang, J.F.; Wang, G.R.; Wang, D.Z.; Han, M.H. Biodiesel production from waste oil feedstocks by solid acid catalysis. Process Saf. Environ. Prot. 2008. [CrossRef]

108. Kafuku, G.; Lee, K.T.; Mbarawa, M. The use of sulfated tin oxide as solid superacid catalyst for heterogeneous transesterification of Jatropha curcas oil. Chem. Pap. 2010. [CrossRef] 
109. Kafuku, G.; Lam, M.K.; Kansedo, J.; Lee, K.T.; Mbarawa, M. Heterogeneous catalyzed biodiesel production from Moringa oleifera oil. Fuel Process. Technol. 2010. [CrossRef]

110. Kafuku, G.; Lam, M.K.; Kansedo, J.; Lee, K.T.; Mbarawa, M. Croton megalocarpus oil: A feasible non-edible oil source for biodiesel production. Bioresour. Technol. 2010. [CrossRef]

111. Yee, K.F.; Lee, K.T.; Ceccato, R.; Abdullah, A.Z. Riccardo Ceccato Production of biodiesel from Jatropha curcas L. oil catalyzed by SO42-/ZrO2 catalyst: Effect of interaction between process variables. Bioresour. Technol. 2011, 102, 4285-4289. [CrossRef]

112. Zanette, A.F.; Barella, R.A.; Pergher, S.B.C.; Treichel, H.; Oliveira, D.; Mazutti, M.A.; Silva, E.A.; Oliveira, J.V. Screening, optimization and kinetics of Jatropha curcas oil transesterification with heterogeneous catalysts. Renew. Energy 2011. [CrossRef]

113. Semwal, S.; Arora, A.K.; Badoni, R.P.; Tuli, D.K. Biodiesel production using heterogeneous catalysts. Bioresour. Technol. 2011, 102, 2151-2161. [CrossRef] [PubMed]

114. Rabiah Nizah, M.F.; Taufiq-Yap, Y.H.; Rashid, U.; Teo, S.H.; Shajaratun Nur, Z.A.; Islam, A. Production of biodiesel from non-edible Jatropha curcas oil via transesterification using $\mathrm{Bi}_{2} \mathrm{O}_{3}-\mathrm{La}_{2} \mathrm{O}_{3}$ catalyst. Energy Convers. Manag. 2014. [CrossRef]

115. Lin, V.S.-Y.; Nieweg, J.A.; Kern, C.; Trewyn, B.G.; Wiench, J.W.; Pruski, M. Acid-base mesoporous calcia-silica catalysts for cooperative conversion of bio-based feedstocks into biodiesel. Prepr. Symp. Am. Chem. Soc. Div. Fuel Chem. 2006, 51, 426-427.

116. Wan Omar, W.N.N.; Amin, N.A.S. Biodiesel production from waste cooking oil over alkaline modified zirconia catalyst. Fuel Process. Technol. 2011. [CrossRef]

117. Lin, V.S.Y.; Nieweg, J.A.; Verkade, J.G.; Venkat, R.; Reddy, C.; Kern, C. New Composite Based Catalysts for Biodiesel Production. Patent WO 2008/013551 A1, 31 January 2008.

118. Lee, H.V.; Juan, J.C.; Taufiq-Yap, Y.H. Preparation and application of binary acid-base $\mathrm{CaO}_{-} \mathrm{La}_{2} \mathrm{O}_{3}$ catalyst for biodiesel production. Renew. Energy 2015. [CrossRef]

119. Salinas, D.; Guerrero, S.; Araya, P. Transesterification of canola oil on potassium-supported $\mathrm{TiO}_{2}$ catalysts. Catal. Commun. 2010. [CrossRef]

120. Jiménez-López, A.; Jiménez-Morales, I.; Santamaría-González, J.; Maireles-Torres, P. Biodiesel production from sunflower oil by tungsten oxide supported on zirconium doped MCM-41 silica. J. Mol. Catal. A Chem. 2011. [CrossRef]

121. Cannilla, C.; Bonura, G.; Rombi, E.; Arena, F.; Frusteri, F. Highly effective MnCeOx catalysts for biodiesel production by transesterification of vegetable oils with methanol. Appl. Catal. A Gen. 2010. [CrossRef]

122. Gonçalves, A.P.V.; Lopes, J.M.; Lemos, F.; Ramôa Ribeiro, F.; Prazeres, D.M.F.; Cabrai, J.M.S.; Aires-Barros, M.R. Zeolites as supports for enzymatic hydrolysis reactions. Comparative study of several zeolites. J. Mol. Catal. B Enzym. 1996. [CrossRef]

123. Huge-Jensen, B.; Galluzzo, D.R.; Jensen, R.G. Studies on free and immobilized lipases from Mucor miehei. J. Am. Oil Chem. Soc. 1988. [CrossRef]

124. Oliveira, A.C.; Rosa, M.F.; Cabral, J.M.S.; Aires-Barros, M.R. Immobilization of saccharomyces cerevisiae cells and rhizomocur miehei lipase for the production and extractive biocatalysis of ethanol. Bioprocess Eng. 1997. [CrossRef]

125. Fukuda, H.; Hama, S.; Tamalampudi, S.; Noda, H. Whole-cell biocatalysts for biodiesel fuel production. Trends Biotechnol. 2008, 26, 668-673. [CrossRef] [PubMed]

126. Nielsen, P.M.; Brask, J.; Fjerbaek, L. Enzymatic biodiesel production: Technical and economical considerations. Eur. J. Lipid Sci. Technol. 2008, 110, 692-700. [CrossRef]

127. Sarno, M.; Iuliano, M. Active biocatalyst for biodiesel production from spent coffee ground. Bioresour. Technol. 2018. [CrossRef]

128. Saranya, G.; Ramachandra, T.V. Novel biocatalyst for optimal biodiesel production from diatoms. Renew. Energy 2020. [CrossRef]

129. Chen, G.; Liu, J.; Yao, J.; Qi, Y.; Yan, B. Biodiesel production from waste cooking oil in a magnetically fluidized bed reactor using whole-cell biocatalysts. Energy Convers. Manag. 2017. [CrossRef]

130. Zhong, L.; Feng, Y.; Wang, G.; Wang, Z.; Bilal, M.; Lv, H.; Jia, S.; Cui, J. Production and use of immobilized lipases in/on nanomaterials: A review from the waste to biodiesel production. Int. J. Biol. Macromol. 2020, 152, 207-222. [CrossRef] 
131. Akubude, V.C.; Nwaigwe, K.N.; Dintwa, E. Production of biodiesel from microalgae via nanocatalyzed transesterification process: A review. Mater. Sci. Energy Technol. 2019. [CrossRef]

132. Liu, D.M.; Dong, C. Recent advances in nano-carrier immobilized enzymes and their applications. Process Biochem. 2020, 92, 464-475. [CrossRef]

133. Kim, K.H.; Lee, O.K.; Lee, E.Y. Nano-immobilized biocatalysts for biodiesel production from renewable and sustainable resources. Catalysts 2018, 8, 68 .

134. Miao, C.; Yang, L.; Wang, Z.; Luo, W.; Li, H.; Lv, P.; Yuan, Z. Lipase immobilization on amino-silane modified superparamagnetic $\mathrm{Fe}_{3} \mathrm{O}_{4}$ nanoparticles as biocatalyst for biodiesel production. Fuel 2018. [CrossRef]

135. Nematian, T.; Salehi, Z.; Shakeri, A. Conversion of bio-oil extracted from Chlorella vulgaris micro algae to biodiesel via modified superparamagnetic nano-biocatalyst. Renew. Energy 2020. [CrossRef]

136. Narayanan, C.M.; Pandey, A. Studies on biodiesel synthesis using nanosilica immobilised lipase in inverse fluidized bed bioreactors. J. Adv. Chem. 2018. [CrossRef]

137. Banerjee, S.; Rout, S.; Banerjee, S.; Atta, A.; Das, D. $\mathrm{Fe}_{2} \mathrm{O}_{3}$ nanocatalyst aided transesterification for biodiesel production from lipid-intact wet microalgal biomass: A biorefinery approach. Energy Convers. Manag. 2019. [CrossRef]

138. Antunes, W.M.; de Oliveira Veloso, C.; Henriques, C.A. Transesterification of soybean oil with methanol catalyzed by basic solids. Catal. Today 2008. [CrossRef]

139. Sreeprasanth, P.S.; Srivastava, R.; Srinivas, D.; Ratnasamy, P. Hydrophobic, solid acid catalysts for production of biofuels and lubricants. Appl. Catal. A Gen. 2006. [CrossRef]

140. Yang, Z.; Xie, W. Soybean oil transesterification over zinc oxide modified with alkali earth metals. Fuel Process. Technol. 2007. [CrossRef]

141. Xu, L.; Yang, X.; Yu, X.; Guo, Y. Maynurkader preparation of mesoporous polyoxometalate-tantalum pentoxide composite catalyst for efficient esterification of fatty acid. Catal. Commun. 2008. [CrossRef]

142. Petchmala, A.; Laosiripojana, N.; Jongsomjit, B.; Goto, M.; Panpranot, J.; Mekasuwandumrong, O.; Shotipruk, A. Transesterification of palm oil and esterification of palm fatty acid in near- and super-critical methanol with $\mathrm{SO}_{4}-\mathrm{ZrO}_{2}$ catalysts. Fuel 2010. [CrossRef]

143. McNeff, C.V.; McNeff, L.C.; Yan, B.; Nowlan, D.T.; Rasmussen, M.; Gyberg, A.E.; Krohn, B.J.; Fedie, R.L.; Hoye, T.R. A continuous catalytic system for biodiesel production. Appl. Catal. A Gen. 2008. [CrossRef]

144. Sani, Y.M.; Daud, W.M.A.W.; Abdul Aziz, A.R. Solid acid-catalyzed biodiesel production from microalgal oil-The dual advantage. J. Environ. Chem. Eng. 2013, 1, 113-121. [CrossRef]

145. Dong, T.; Wang, J.; Miao, C.; Zheng, Y.; Chen, S. Two-step in situ biodiesel production from microalgae with high free fatty acid content. Bioresour. Technol. 2013. [CrossRef] [PubMed] 